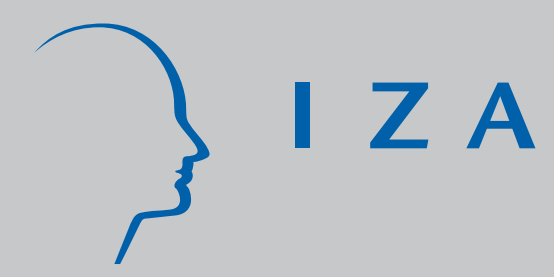

IZA DP No. 922

Working Hour Arrangements and Working Hours A Microeconometric Analysis Based on German Time Use Diary Data

J oachim Merz

Derik Burgert

November 2003 


\title{
Working Hour Arrangements and Working Hours - A Microeconometric Analysis Based on German Time Use Diary Data
}

\author{
Joachim Merz \\ University of Lueneburg and IZA Bonn \\ Derik Burgert \\ University of Lueneburg
}

Discussion Paper No. 922

November 2003

\author{
IZA \\ P.O. Box 7240 \\ D-53072 Bonn \\ Germany \\ Tel.: +49-228-3894-0 \\ Fax: +49-228-3894-210 \\ Email: iza@iza.org
}

This Discussion Paper is issued within the framework of IZA's research area The Future of Labor. Any opinions expressed here are those of the author(s) and not those of the institute. Research disseminated by IZA may include views on policy, but the institute itself takes no institutional policy positions.

The Institute for the Study of Labor (IZA) in Bonn is a local and virtual international research center and a place of communication between science, politics and business. IZA is an independent, nonprofit limited liability company (Gesellschaft mit beschränkter Haftung) supported by Deutsche Post World Net. The center is associated with the University of Bonn and offers a stimulating research environment through its research networks, research support, and visitors and doctoral programs. IZA engages in (i) original and internationally competitive research in all fields of labor economics, (ii) development of policy concepts, and (iii) dissemination of research results and concepts to the interested public. The current research program deals with (1) mobility and flexibility of labor, (2) internationalization of labor markets, (3) welfare state and labor market, (4) labor markets in transition countries, (5) the future of labor, (6) evaluation of labor market policies and projects and (7) general labor economics.

IZA Discussion Papers often represent preliminary work and are circulated to encourage discussion. Citation of such a paper should account for its provisional character. A revised version may be available on the IZA website (www.iza.org) or directly from the author. 
IZA Discussion Paper No. 922

November 2003

\section{ABSTRACT \\ Working Hour Arrangements and Working Hours - A Microeconometric Analysis Based on German Time Use Diary Data}

The labour market providing individual resources and economic well-being is an actual topic in the economic and social policy discussion. In the course of time the traditional full-time work is diminishing, new labour arrangements are discussed (keyword: flexible labour markets). This study will contribute to the discussion of working hour arrangements by quantifying patterns of explanation of 'who is working when within a workday'. In particular we want to disentangle certain working hour patterns and the final hours of work according to those different patterns allowing for market and non-market influences. The daily working hour patterns are analysed by two dimensions: the fragmentation of a working day (by the number of working episodes) and the timing of work time by location of those episodes within the day's period. Based on an extended microeconomic labour supply/household production our microeconometric estimates use a multinomial logit (MNL) model to explain the working hour arrangement probability and a MNL selectivity bias corrected hours estimation for arrangement specific working hours with correct asymptotic covariances. Our study is the first German study of this kind which could analyse the actual available German Time Use Survey 1991/92 from the Federal Statistical Office with ca. 32.000 time diaries.

JEL Classification: J22, J29

Keywords: $\quad$ working hour arrangements, timing of work time, working hours, German time budget study, time use diary data, discrete/continuous extended labour supply modeling, MNL/COLS-estimation

Corresponding author:

Joachim Merz

Department of Economics and Social Sciences

University of Lueneburg

Campus Scharnhorststr. 1

21335 Lueneburg

Germany

Tel.: +49 4131782051

Fax: +494131782059

Email: merz@uni-lueneburg.de 


\section{TABLE OF CONTENTS}

$1 \quad$ Introduction

2 Working Hours and Working Hour Arrangements - Microeconomic Approach

3 Data: The German Time Budget Survey 1991/1992 7

3.1 Diary and additional household and personal variables $\quad 7$

3.2 Data consideration for our analysis 9

4 Working Hour Arrangements, Working Hours and Socio-economic Variables - Descriptive Results

4.1 Methodology: Working Hour Arrangement Categories 9

4.2 Working Hour Arrangements by Socioeconomic Variables 11

$5 \quad$ Working Hour Arrangements - Econometrics and Results 14

5.1 Estimating potential wages for non workers: A selectivity bias corrected PROBIT/COLS approach

5.2 Explaining Participation in Working Hour Arrangement Categories by a Multinomial Logit (MNL)-Model

6 Working Hours in a market and non-market context - Econometrics and Results

6.1 Microeconometric Specification: A MNL/COLS Arrangement Specific Working Hour Model

6.2 Explaining Arrangement Specific Working Hours in a market and non-market context

7 Concluding Remarks $\quad 27$

$\begin{array}{ll}\text { Appendix } & \mathbf{2 8}\end{array}$

$\begin{array}{lr}\text { References } & \mathbf{3 0}\end{array}$ 


\title{
Working Hour Arrangements and Working Hours - A Microeconometric Analysis Based on German Time Diary Data
}

\author{
Joachim Merz and Derik Burgert
}

\section{Introduction}

The labour market providing individual resources and economic well-being is a central topic in the economic and social policy discussion. In the course of time the traditional full-time work is diminishing, new labour arrangements are discussed (keyword: flexible labour markets). ${ }^{1}$

This study will contribute to the discussion of working hour arrangements by quantifying patterns of explanation of 'who is working when within a workday'. In particular we want to disentangle certain working hour patterns - with focus on the fragmentation (interruptions) of a working day crossed by the location of the working period - and the final hours of work according to these different arrangement patterns allowing for market and non-market influences. Deducting such patterns allows not only to describe possible fragmented workday interruptions and workday behaviour in general, but to give hints for which groups of the society non-traditional working time is important. Once quantified, labour market policy and economic and social policy in general has a sound base for a targeted policy.

Studies of working hours have a long tradition within labour economics and particular labour supply analyses (see e.g. Killingsworth 1983 and the surveys about female and male labour supply by Killingsworth and Heckman 1986 resp. Pencavel 1986). Within labour supply, working hour arrangements subjects like overtime or working across the week or the weekend are analysed and discussed. ${ }^{2}$ Typically these topics and studies investigate aggregate time patterns still in the tradition of typical labour supply models explaining weekly supplied working hours or yearly working days.

However, only a few empirically and theoretically based labour supply studies on working hour arrangements address the question 'who is working when within a workday' (Hamermesh 1996a,b, 1998, 2002; Harvey et al. 2000 or Callister and Dixon 2001). Hamermesh (1996a, p.1) describes this topic by the timing of work time when analysing 'instantaneous time use - of what people are doing at particular points of the workday and workweek' and provides a discussion of appropriate recent results.

\footnotetext{
${ }^{1}$ Flexible labour markets are discussed under various topics. To mention only a few: social policy and the working time (Büssing, and Seifert 1995), firm side working time arrangements (Baur, Groß, Munz and Sayin 2001), time squeeze (Clarkberg and Moen 2000), working hour tension as the tension between desired and actual working hours (Merz 2002, Holst and Schupp 1994) or effects of flexible working hours to leisure and family (Garhammer 1994, Townsend 2001) or tax and transfer policy impacts on the formal and informal economy (Merz 1990).
}

2 Working time accounts provide practical labour arrangement solutions (see the recent contracts within VW or other German firms). 
This novel view of working hours arrangements based on individual data like the German Socio-Economic Panel is investigated by e.g. Hamermesh 1996. Though very interesting insides are given there, however, the data behind is still aggregated in some sense. What is needed are microanalyses based on time use diaries which indeed document when people work over the day. Internationally there are only some of such working time arrangement studies based on time use diaries available: e.g. the mentioned study by Harvey et al. 2000 comparing four countries in the early 90ies (Canada, the Netherlands, Norway and Sweden) or Callister and Dixon 2001 based on the New Zealand Time Use Survey 1998/99.

Our model is based on a microeconomic labour supply/household production approach, however extended by two dimensions: first, by daily working arrangements with focus on core and non-core working time (location) crossed by number of episodes (fragmentation) and, second, by labour demand factors in a market and non-market context. Our microeconometric estimates use a multinomial logit (MNL) model to explain the working hour arrangement probability and a MNL selectivity bias corrected hours estimation for arrangement specific working hours with correct asymptotic covariances.

For Germany, our study is the first study in this sense which could analyse the actual available German Time Use Survey 1991/92 from the Federal Statistical Office with ca. 32.000 time diaries. ${ }^{3}$

Our contribution is embedded in the general time use research area. A recent survey about research, data and policy topics is given e.g. in Merz and Ehling 1999, Harvey 1999 and Merz 2002.

\section{Paper organisation:}

We start with the microeconomic intertemporal 'new home economics' approach as the principal theoretical base of our labour market analysis and specify our prominent final model parts: explaining the participation in a certain working hour arrangement, and depending on that selection, explaining working hours in the context of market and non-market activities. Chapter 3 describes the time diary data used, the actual available German Time Use Survey 1991/92. Chapter 4 explains our approach to capture the timing of work time as well as the kind of interruptions in different working hour arrangement categories and presents descriptive results of working time arrangements in Germany. In chapter 5 we turn to inferential statistics estimating the probability to choose one of the categories defined. In chapter 6 we explain final hours of working dependent on the differrent working hour arrangement categories. Chapter 7 concludes.

\section{$2 \quad$ Working Hours and Working Hour Arrangements - Microeconomic Approach}

The well-known 'new home economics' (Becker 1965) could provide a microeconomic theoretical framework for the timing of work time: the intertemporal approach explains the decision how many hours in which period out of a number of periods labour are supplied, and in addition, the 'new home economics' approach shows a way how market and non-market (home production) labour activities could be incorporated.

\footnotetext{
${ }^{3}$ Within these days, the new German Time Use Survey 2001/2002 will be available. Our study here will be the base then to analyse the appropriate developments within the last decade.
} 
There, a rational worker maximizes the present value of a stream of utility $u_{t}$ which is dependent on the household production output quantity $z_{t}$ and socio-economic variables. The individual is restricted by its time $\mathrm{h}_{\mathrm{t}}=\mathrm{h}_{\mathrm{mt}}+\mathrm{h}_{\mathrm{nt}}$ (market and non-market hours) and its budget as the discounted (discounted by the market rate i) earned income - out of labour income $\mathrm{w}_{\mathrm{t}} \mathrm{h}_{\mathrm{mt}}$ and non-labour income $\mathrm{V}_{\mathrm{t}}$ - and a possible additional starting asset. Non-market time $\mathrm{h}_{\mathrm{nt}}$ and market goods $\mathrm{x}_{\mathrm{t}}$ at prices $\mathrm{p}_{\mathrm{t}}$ are combined to produce the household commodities $\mathrm{z}_{\mathrm{t}}=\mathrm{f}\left(\mathrm{x}_{\mathrm{t}}, \mathrm{h}_{\mathrm{nt}}\right)$.

Then the intertemporal utility maximization subject to the time and money restrictions via

$$
\begin{aligned}
& \max _{\mathrm{xt}, \mathrm{hnt}}\left\{\mathrm{u}\left(\mathbf{z}_{0}, \ldots, \mathbf{z}_{\mathrm{T}} ; \mathbf{q}_{0}, \ldots, \mathbf{q}_{\mathrm{T}}\right)=\Sigma_{\mathrm{t}} \mathrm{u}_{\mathrm{t}}\left(\mathbf{z}_{\mathrm{t}} ; \mathbf{q}_{\mathrm{t}}\right)(1+\mathrm{s})^{-\mathrm{t}}, \mid\right. \\
& \mathbf{z}_{\mathrm{t}}=\mathrm{f}_{\mathrm{t}}\left(\mathrm{x}_{\mathrm{t}}, \mathrm{h}_{\mathrm{nt}}\right), \\
& \mathrm{h}=\mathrm{h}_{\mathrm{mt}}+\sum_{\mathrm{r}} \mathrm{h}_{\mathrm{ntr}}, \\
& \left.\sum_{\mathrm{t}} \mathbf{p}_{\mathrm{t}} \mathbf{x}_{\mathrm{t}}(1+\mathrm{i})^{-\mathrm{t}} \leq \mathrm{A}_{\mathrm{o}}+\sum_{\mathrm{t}}\left(\mathrm{w}_{\mathrm{t}} \mathrm{h}_{\mathrm{mt}}+\mathrm{V}_{\mathrm{t}}\right)(1+\mathrm{i})^{-\mathrm{t}}\right\}
\end{aligned}
$$

with $\mathrm{s}$ as the individual time preference rate yields the optimal allocation equations for consumption $\mathrm{x}_{\mathrm{t}}$, non-market time $\mathrm{h}_{\mathrm{nt}}$ (eventually further disaggregated within the household production function to $m$ multiple non-market hours $h_{n t r}(r=1, \ldots, m)$, and market hours supplied

$$
\begin{aligned}
& \mathrm{h}_{\mathrm{nt}}=\mathrm{h}_{\mathrm{nt}}\left(\gamma \delta_{\mathrm{t}} \mathrm{w}_{\mathrm{t}}, \gamma \delta_{\mathrm{t}} \mathrm{P}_{\mathrm{t}}, \mathrm{S} ; \mathbf{q}_{\mathrm{t}}\right)=\mathrm{h}_{\mathrm{nt}}\left(\gamma \delta_{\mathrm{t}} \mathrm{w}_{\mathrm{t}}, \gamma \delta_{\mathrm{t}} \mathrm{P}_{\mathrm{t}}, \mathrm{V}_{\mathrm{t}}, \mathrm{A}_{0} ; \mathbf{q}_{\mathrm{t}}\right) \\
& \mathrm{h}_{\mathrm{mt}}=\mathrm{h}-\mathrm{h}_{\mathrm{nt}}=\mathrm{h}_{\mathrm{mt}}\left(\gamma \delta_{\mathrm{t}} \mathrm{w}_{\mathrm{t}}, \gamma \delta_{\mathrm{t}} \mathrm{P}_{\mathrm{t}}, \mathrm{S} ; \mathbf{q}_{\mathrm{t}}\right)=\mathrm{h}_{\mathrm{mt}}\left(\gamma \delta_{\mathrm{t}} \mathrm{w}_{\mathrm{t}}, \gamma \delta_{\mathrm{t}} \mathrm{P}_{\mathrm{t}}, \mathrm{V}_{\mathrm{t}}, \mathrm{A}_{0} ; \mathbf{q}_{\mathrm{t}}\right) \\
& \mathrm{h}_{\mathrm{ntr}}=\mathrm{h}_{\mathrm{ntr}}\left(\gamma \delta_{\mathrm{t}} \mathrm{w}_{\mathrm{t}}, \gamma \delta_{\mathrm{t}} \mathrm{P}_{\mathrm{t}}, \mathrm{V}_{\mathrm{t}}, \mathrm{A}_{0}, \mathrm{f}_{\mathrm{rxt}} ; \mathbf{q}_{\mathrm{t}}\right), \quad(\mathrm{r}=1, \ldots, \mathrm{m}),
\end{aligned}
$$

where $\left.\mathrm{S}=\mathrm{A}_{\mathrm{o}}+\sum_{\mathrm{t}}\left(\mathrm{w}_{\mathrm{t}} \mathrm{h}_{\mathrm{mt}}+\mathrm{V}_{\mathrm{t}}\right)(1+\mathrm{i})^{-\mathrm{t}}\right\}, \mathrm{f}_{\text {rxt }}$ is marginal home production and $\delta_{\mathrm{t}}=(1+\mathrm{s})^{\mathrm{t}}(1+\mathrm{i})^{-\mathrm{t}}$ are $\gamma$-constant or Frisch labour supply resp. activity supply functions. 4

With regards to interruptions within a workday in addition one can think about demand side restrictions and involuntary unemployment. Such restrictions are captured in constrained labour supply analyses (for the market case only) for example by Ham 1982, Blundell, Ham and Meghir 1987, van Soest, Woittiez and Kapteyn 1989 or Osberg and Phipps 1993.

At a first glance this intertemporal approach is nice to model the within a workday intertemporal labour supply decisions. However, the question and the crucial point is the shortness of intervals and the possibility to quantify the approach empirically. A further complication is our wish also to explain a 'normal' workday with only one period which is only a limiting case in the intertemporal approach. Therefore the above model - theoretically interesting but not really suited for the daily perspective - will not be pursued further. However, this microeconomic model will be the framework for the set of hypotheses to be examined.

More appealing is an approach who explicitly models different alternatives, where an individual has to choose one alternative out of a set of working hour patterns. Because our aim is to explain both different working time patterns over the day as well as the final working hours according to such a different pattern, an appropriate approach is a discrete choice random util-

\footnotetext{
${ }^{4}$ Hamermesh 1996 discussed the intertemporal approach (however without the non-matrket extension) in the frame of working hour arrangements over a workday.
} 
ity model for the arrangement decision of a rational individual which then might influence the decision of specific hours of work in two steps:

\section{STEP 1: $\quad$ Categories of working hour arrangements}

A Random Utility Model (RUM) (McFadden 1985) defines which working hour category $\mathrm{j}$ in a day is chosen among $\mathrm{J}+1$ choices by a rational individual via the index function

$$
\mathrm{I}_{\mathrm{j}}=1 \text { if } \mathrm{u}_{\mathrm{j}}=\max \left(\mathrm{u}_{0}, \ldots, \mathrm{u}_{\mathrm{J}}\right) ; \mathrm{I}_{\mathrm{j}}=0 \text { else. }
$$

The appropriate econometric model will be the multinomial logit. Within this model we also consider and estimate selectivity biased corrected potential wages for those who are not working and thus not receiving any wages.

\section{STEP 2: $\quad$ Category dependent daily hours of work}

The appropriate econometric model will be a MNL-selectivity corrected hours of work model for each working hour pattern with a microeconomic reasoning behind

$$
h_{j}=h_{j}(w, V, q \mid \text { category } j) .
$$

This two step model, in particular, allows to analyze the hypothesis, that choosing a particular working hour pattern might be explained by other circumstances than the final amount of hours working. Econometric details are given in the appropriate section in what follows.

\section{Data: The German Time Budget Survey}

The analysis is based on data from the actual available German Time Use Study conducted by the Federal Statistical Office in 1991/92 (e.g. Ehling 1999). The sample contains individuals from 6845 households aged 12 years and older. In contrast to other data collections that report the timing of work during the day the sample at hand connects working time data with those on personal und household background information ${ }^{5}$

\subsection{Diary and additional household and personal variables}

The time use diaries itself constitute the core of the time budget study. They contain the activities listed in five minute intervals reporting for two consecutive days including weekends and holidays ${ }^{6}$. Apart from that the federal statistical office collected household and personal data on the respondents.

\footnotetext{
5 In Germany the "Institut zur Erforschung sozialer Chancen" provides data on operating and working time on a firm level (cf. Bauer et al. (2001)). In addition the IAB firm panel run by the "Institut für Arbeitsmarkt- und Berufsforschung“ comprises information on working time. A survey of the „Deutscher Industrie- und Handelstag" reports data on forms of working time flexibilization.

${ }^{6}$ Beyond a main activity the data contain information on a second activity, on the location, if time was spent with children, other household members, friends or colleges.
} 
Besides some technical variables, the household characteristics can be divided into three groups: First, there is information on the material equipment of the household as the number of cars, microwave ovens etc. Data on household characteristics describe special needs for the time-use of its members as the number of people in need of care living in the household. A third group of variables reflects the type of household as household income or size. Using a regional key one can merge macro data as regional unemployment rates. Table 1 shows some important household variables.

\section{Tab.1: Household characteristics}

\section{German Time Budget Study: Survey characteristics in the household questionnaire}

- Household assembly

- Living and housing conditions

- Household equipment

- Selected household utility goods

- Institution offers in household surroundings

- Total household income (sources and amounts)

- Household members in need of care

Source: $\quad$ German Time Use Study 1991

Even the individual variables can be summarized in three groups: a first one on socioeconomic information of the respondents as e.g. school leaving certificates or gender. A second group consists in information on characteristics that might lead to a specific time use behaviour as if and how long the person regularly helps members of other household. A last bundle of variables reports self-assessment and plans concerning the subject's time use. Some important items are listed in Table 2.

\section{Tab. 2: $\quad$ Personal characteristics}

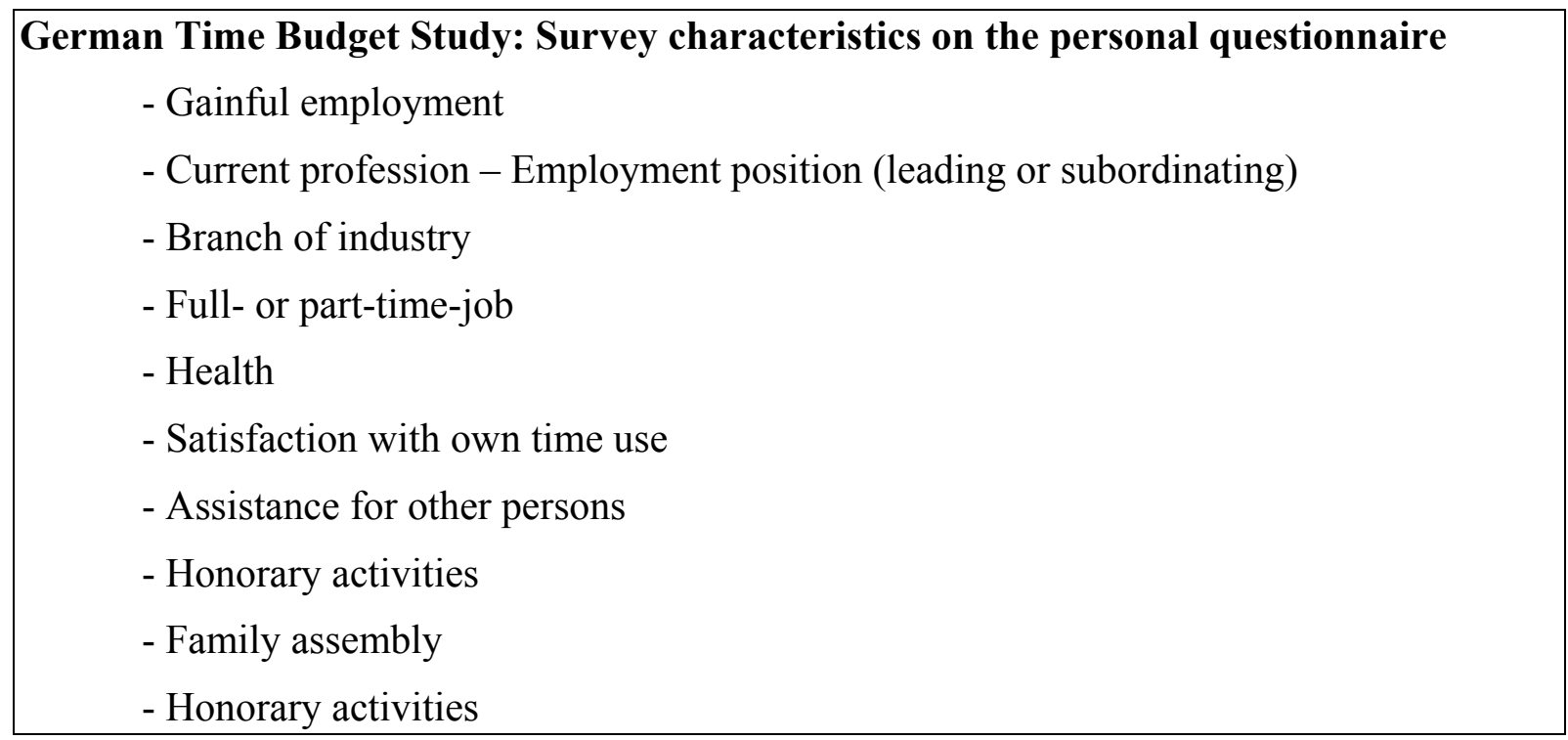




\subsection{Data consideration for our analysis}

The data used for the analysis differ slightly from what is provided by the original data set. As we are analyzing gainful occupation, we have restricted our sample to people aged between 16 and 64. Apart from that we examined only those cases where respondents handed in the time use diaries. For the sake of consistency, we deleted all observations reporting activities of gainful employment but no income. After these restrictions the set contains 24.931 diaries of 12.513 persons in 6.176 households.

For testing our hypotheses we chose variables determined by both theoretical considerations and the necessity to specify a scarce but pronounced set of explanatory factors. With reference to the explicit hypotheses formulation in the following chapters we briefly name the variable set here.

Among the personal characteristics we selected age, gender and family status. Further on, we chose standard variables from human capital theory such as school leaving certificates and occupational education. In order to include demand-side influences derived from the business sector's production functions we considered business sector dummies.

Among those variables traditionally used in labour supply models, we consider a net wage per hour $[\mathrm{DM}]$ - here only available as a proxy as individual monthly income divided by monthly hours of work - as well the income situation of the household. To include more demand-side factors we merged the data set with regional variables as local unemployment rate, per capita, an East Germany dummy and the information if the service sector is predominant in the region.

Variables on activities competing with gainful occupation stem from time use research: time used to for household keeping, for child care and do-it-yourself work. The decision if and when to work might be heavily dependent on one's family context. This led us to control for the partner's regular weekly working time and his occupational status. Apart from that we included the time a person regularly helps other households, and the time the household normally receives help.

Altogether this is a set of variables theoretically based to analyze working hour arrangements and hours of work in different arrangements in a market and non-market context as well as by labour supply and demand side influences.

\section{Working Hour Arrangements and its Determinants - Some Descriptive Results}

Descriptive results and definitions of our working hour arrangement categories and the socioeconomic determining variables are discussed in this chapter.

\subsection{Methodology: Working Hour Arrangement Categories}

From the multitude of the diaries' five minute interval information we first defined working hour arrangement categories which are in the further focus of our investigation. From various possibilities to divide a day we intended to consider a 'normal' as well as a 'non-normal' workday. To catch such an idea based on the richness of time diary information we needed to consider two dimensions: first, an information about the location of the main working time ('when at a day do people work'), second, an information about the number of work episodes for catching a possible fragmented working day by interruptions. 


\section{Fragmented workdays: working episodes}

Any paid market work is regarded to be working time. Working time will not comprise commuting time. In order to allow shorter breaks within a work period, with respect to the international study of Harvey et al. 2000, we interpret breaks shorter than one hour as a within work period break. A new work episode thus only starts after one hour of interruption. A sensitivity analysis also with further break definitions with Table $\mathrm{A}$ in the Appendix shows that with $72,3 \%$ ( 1 episode), 22,4\% ( 2 episodes), 4,3\% (3 episodes) and 1,0\% (4 and more episodes) altogether $27,9 \%$ have more than 2 working episodes a day.

\section{When do people work? The timing of work time}

The location of the work episodes within a day is our second dimension to depict a more dimensional picture as it would be just the 'normal' full day working hours as in traditional studies. For Germany (and as for Austria, Sweden, Norway (see Harvey et al. 2000)) most working episodes start between $7 \mathrm{am}$ and 8 am and end between $4 \mathrm{pm}$ and $5 \mathrm{pm}$ (as in Sweden(see Harvey et al. 2001). Thus we call $7 \mathrm{am}$ to $5 \mathrm{pm}$ period the core working periods and before and after that core the non-core working period. A non-core workday is the timing aspect of an irregular and 'non-normal' workday.

\section{Working hour arrangements: Combining the episode and core information}

Combining the two dimensions, the number of episodes (for fragmentation) and the core/noncore dimension (timing) we get a two by two table of working hour arrangements (Table 3a).

A normal working day will be considered as containing one episode where the work is mainly done during core time. Both off-diagonal categories II and III deviate in one aspect from a regular work day. Workdays of category II report more than one episode of work showing a kind of a fragmented, interrupted working day. Workdays of category III describe a nonnormal timing of work time. Category IV comprises those cases with most irregular working time: working hour arrangements are both fragmented, interrupted, and off-core.

Table $3 \mathrm{a}$ also shows the respective number of unweighted observations. Most frequent is category I with $68.78 \%$ (8262 cases) regular workdays. Category II embraces 576 observations or $4.74 \%, 24.06 \%$ or 2925 cases fall in category III while only $2.43 \%$ corresponding 295 dairies report on the most irregular working hour arrangements in our definitions as described by category IV.

Though most workdays are normal workdays we will keep in mind that more than $30 \%$ are non-normal workdays with irregularities with regard to the timing of work time and the fragmentation of the working day. Among the non-normal workdays, days with multiple work episodes are less frequent with about $7 \%$ of the sample observations. In contrast, work time mainly off-core are more important: Categories III and IV add up to $26 \%$.

Nonetheless it will be obvious by the further table info that our categorization emphasises many additional irregularities.

\footnotetext{
${ }^{7}$ This is in line with a similar definition in the international study by Harvey et al. 2000 .
} 
Tab. 3a: Working hour arrangement categories by fragmentation and timing of work time

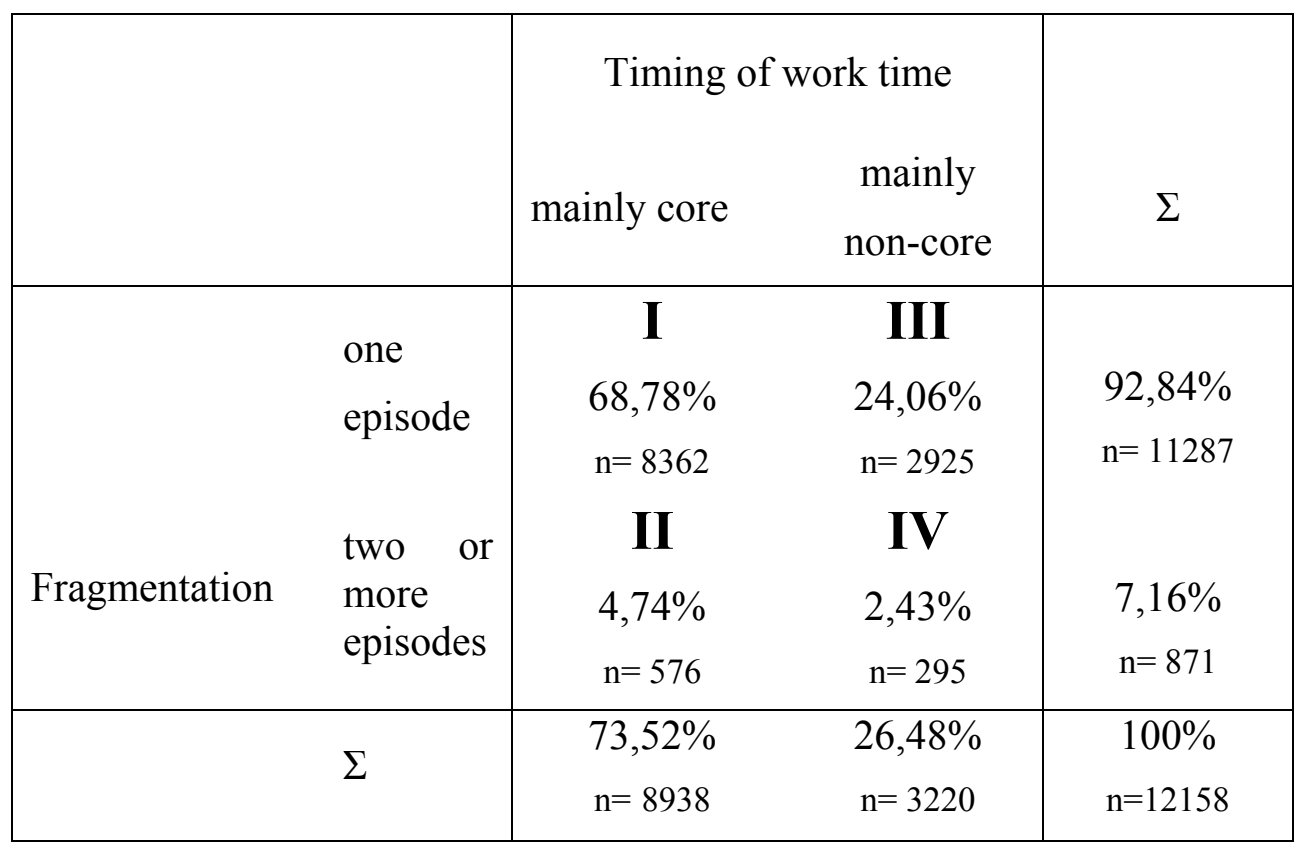

Source: $\quad$ German Time Use Study 1991/92, own calculations

\section{Labour force participation and working hour arrangements}

To compare our kind of working hour arrangement with stylized labour force participationn information also used in other non-diary studies Table $3 \mathrm{~b}$ provides respective information. A typical categorization is into a full- and part-time job, which also is available from our respondents. The allover full-time quota is $80,4 \%$, the part-time quota is $18,1 \%$. This is quite similar to other studies' quotas: the German Socioeconomic Panel (GSOEP) is delivering a full-time quota of $81,2 \%$ and a part-time quota of $15,3 \%$ (West Germany, 1991, weighted values; Schupp 1994). A prominent reason for a part-time job: because of having more time for the family $(38,5 \%)$.

Our further time-diary based categorization shows that the one episode categories (I and III) are by more than $80 \%$ full time jobs, respectively, $18 \%$ resp. $13 \%$ of all working in the one episode cases work part time. The part-time quota is pronounced higher in the more episode cases: $37 \%$ (core) and 25,4\% (non-core). Though most of the more episode cases are belonging to one job, however, in particular the second job quota is double as high in non-core jobs (ca. 12\%) compared to core jobs.

Interestingly, the reasons for part-time jobs in the early 1990ies in Germany differ remarkably over the working hour arrangement categories. Beyond the 'other reasons', more time for family is allover dominant, highest in the one episode case $(40,8 \%)$ and lowest in the more than one episode case $(32,9 \%)$, both core. Remarkably, 'no child care found' is a prominent reason for a fragmented core working hour arrangement (13,6\%, category II).

To summarize the correspondence of labour force participation with the irregularity/fragmentation of a work day: One episode: most full time ${ }^{8)}, \geq 2$ episodes: most part time work, non-core: most second jobs.

\footnotetext{
${ }^{8}$ Comparison over all respective working hour arrangements (columns of Table $3 \mathrm{~b}$ ).
} 
Tab. 3b: Labour force participation and working hour arrangements

\begin{tabular}{|c|c|c|c|c|c|}
\hline & $\begin{array}{c}\text { All } \\
\text { working }\end{array}$ & $\begin{array}{c}\text { Category } \\
\text { I }\end{array}$ & $\begin{array}{c}\text { Category } \\
\text { II }\end{array}$ & $\begin{array}{l}\text { Category } \\
\text { III }\end{array}$ & $\begin{array}{c}\text { Category } \\
\text { IV }\end{array}$ \\
\hline & Working & $\begin{array}{c}\text { One episode }- \\
\text { core }\end{array}$ & $\begin{array}{c}\text { \# episodes } \\
\geq 2 \\
\text { core }\end{array}$ & $\begin{array}{c}\text { One episode }- \\
\text { non-core }\end{array}$ & $\begin{array}{c}\text { \# episodes } \\
\geq 2 \\
\text { non-core }\end{array}$ \\
\hline Full-time & 80,4 & 80,2 & 60,1 & 85,8 & 72,9 \\
\hline Part-time & 18,1 & 18,3 & 37,0 & 13,1 & 25,4 \\
\hline \multicolumn{6}{|c|}{ Part-time reasons ${ }^{I}$} \\
\hline $\begin{array}{l}\text { No Full-time } \\
\text { job found }\end{array}$ & 5,1 & 4,6 & 6,6 & 5,7 & 8,0 \\
\hline $\begin{array}{l}\text { Vocational } \\
\text { training }\end{array}$ & 4,1 & 3,7 & 6,1 & 4,4 & 4,0 \\
\hline $\begin{array}{l}\text { No } \quad \text { Child } \\
\text { Care found }\end{array}$ & 8,9 & 9,2 & 13,6 & 6,3 & 4,0 \\
\hline $\begin{array}{l}\text { More time } \\
\text { for family }\end{array}$ & 38,5 & 40,8 & 32,9 & 33,6 & 33,3 \\
\hline $\begin{array}{l}\text { Other rea- } \\
\text { sons }\end{array}$ & 43,4 & 41,7 & 40,8 & 50,0 & 50,7 \\
\hline Others & 1,4 & 1,4 & 3,0 & 1,1 & 1,7 \\
\hline Second job & 7,2 & 5,4 & 6,9 & 11,7 & 11,9 \\
\hline
\end{tabular}

All data in $\%$ of all column specific working

1) in \% of all part-time workers

Source: German Time Use Study 1991/92, own calculations

\subsection{Working Hour Arrangements by Socioeconomic Variables}

In a first approach to an empirical answer to the question what determines the choice of the working hour arrangement we employ simple, univariate statistical methods. Differentiating between personal, household and regional variables we briefly describe sample means and shares of socioeconomic variables conditional on the five categories (including the non-work one). The single results can be found in Table 4 .

The overall striking results: Our working hour arrangement categories are caused by major differences in socio-economic influences, emphasizing the importance of these arrangements.

Starting with personal variables, people working mainly off-core are a bit older on average than those working predominantly between $7 \mathrm{am}$ and $5 \mathrm{pm}$. Women's share among nonworkers is higher than in all working categories. It is especially low in mainly non-core categories. Being married is an attribute more often seen among respondents with work activity. The share is even higher in categories II and IV, the fragmented ones.

Regarding the schooling variables we find hints that the high school leaving certificates 'special upper' and 'upper' can be observed more often in the non-fragmented categories I and III, while persons working more than one episode a day show a relatively high proportion of ele- 
mentary school degree only. So, schooling seems to 'protect' from working in multiple episodes but not from working at irregular working times of the day.

For the occupational education, category III workers hold rather high degrees while the proportion of former apprentices is low compared to other categories. The educational structures of the regular workers do not show very large differences to the remaining three categories. Working with interruptions during the day (category II) seems to be a phenomenon of respondents with comparatively poor occupational education. Among category IV members there is no stable trend: both apprenticeship and university degree are pronounced here.

Hours of regular help for other households is highest on average among the non-workers, followed by persons who work in category II. Of course, the observation "weekdays" is more often seen in dairies with episodes of work than in those without any work activity. The interrupted categories contain a comparatively large share of weekend observations. People not working or working in the off-core category III are more likely to be content with their own time use behaviour than all other respondents.

The wage indeed is different and has it highest mean value in the non-core/one episode case (see the next chapter for our imputation of a potential wage for non-workers)..

The partner characteristics differ from one category to another: his or her regular weekly working time is considerably longer for non-core workers. The same applies to having a selfemployed partner. This attribute is relatively most often observed in non-core categories III and IV. Differences can be observed with regard to the partner's occupation. This already indicates the importance of the household connection in explaining working hours and working hour arrangements.

The average number of persons in the household does not differ strongly between the different types of working time behaviour whereas regular help from other household is much more given to households whose members do work supporting their labour force participation.

Respondents reporting a regular work day (category I) live on average in regions with rather high unemployment and lower GNP per capita. They live to a greater extend in the area of the former GDR.

Already these very brief descriptive results show the importance of the explanatory factors regarded. More details are given in Table 4.

Since such a descriptive approach ignores the interdependencies and the relative importance of the single items, a multivariate analysis is needed in order to provide additional statements about the significance of the influencing factors. Such an analysis is now following. 
Tab. 4: Descriptives: Personal characteristics by working hour arrangement categories

\begin{tabular}{|c|c|c|c|c|c|}
\hline & $\begin{array}{c}\text { Category } 0 \\
\text { Not working }\end{array}$ & $\begin{array}{c}\text { Category I } \\
\text { One episode } \\
\text { core }\end{array}$ & $\begin{array}{l}\text { Category II } \\
\text { \# episodes } \\
\geq 2 \\
\text { core }\end{array}$ & $\begin{array}{l}\text { Category III } \\
\text { One episode } \\
\text { non-core }\end{array}$ & $\begin{array}{c}\text { Category IV } \\
\text { \# episodes } \\
\geq 2 \\
\text { non-core }\end{array}$ \\
\hline \multicolumn{6}{|c|}{ PERSONAL CHARACTERISTICS } \\
\hline age & 39.21 & 39.21 & 39.10 & 40.45 & 41.03 \\
\hline woman $[\%]$ & $62.59 \%$ & $42.62 \%$ & $45.14 \%$ & $35.15 \%$ & $37.29 \%$ \\
\hline married $[\%]$ & $66.09 \%$ & $71.12 \%$ & $75.00 \%$ & $72.41 \%$ & $74.58 \%$ \\
\hline \multicolumn{6}{|c|}{ school leaving certificate } \\
\hline elemantary $[\%]$ & $35.33 \%$ & $32.67 \%$ & $43.23 \%$ & $30.50 \%$ & $41.36 \%$ \\
\hline intermediate [\%] & $25.12 \%$ & $23.62 \%$ & $24.13 \%$ & $24.10 \%$ & $20.68 \%$ \\
\hline spec. Upper $[\%]$ & $5.32 \%$ & $6.79 \%$ & $5.03 \%$ & $8.00 \%$ & $4.41 \%$ \\
\hline upper $[\%]$ & $27.10 \%$ & $36.41 \%$ & $25.35 \%$ & $36.92 \%$ & $32.54 \%$ \\
\hline \multicolumn{6}{|c|}{ occupational education } \\
\hline $\begin{array}{l}\text { apprentice [\%] } \\
\text { spec. Vocational }\end{array}$ & $51.88 \%$ & $54.60 \%$ & $59.03 \%$ & $44.58 \%$ & $58.64 \%$ \\
\hline $\begin{array}{l}\text { [\%] } \\
\text { spec. college }\end{array}$ & $10.57 \%$ & $15.77 \%$ & $13.19 \%$ & $17.13 \%$ & $15.25 \%$ \\
\hline$[\%]$ & $4.86 \%$ & $7.88 \%$ & $2.95 \%$ & $9.37 \%$ & $4.41 \%$ \\
\hline university [\%] & $6.35 \%$ & $10.48 \%$ & $7.64 \%$ & $17.64 \%$ & $15.93 \%$ \\
\hline $\begin{array}{l}\text { hours of regular } \\
\text { help to other hhs }\end{array}$ & 1.32 & 0.75 & 1.11 & 0.80 & 1.00 \\
\hline workday [\%] & $57.73 \%$ & $94.07 \%$ & $77.08 \%$ & $93.23 \%$ & $74.24 \%$ \\
\hline $\begin{array}{l}\text { Content of own } \\
\text { time use [\%] }\end{array}$ & $39.83 \%$ & $24.36 \%$ & $26.91 \%$ & $22.36 \%$ & $22.71 \%$ \\
\hline $\begin{array}{l}\text { (potential) wage } \\
{[D M]}\end{array}$ & 24.51 & 19.46 & 19.71 & 27.75 & 18.83 \\
\hline \multicolumn{6}{|c|}{$\begin{array}{l}\text { PARTNER'S CHARACTERISTICS } \\
\text { normal weekly } \\
\text { working time }\end{array}$} \\
\hline \multicolumn{6}{|c|}{ partner`s employment status } \\
\hline $\begin{array}{l}\text { self-employed } \\
{[\%]}\end{array}$ & $6.65 \%$ & $6.34 \%$ & $7.81 \%$ & $12.03 \%$ & $13.90 \%$ \\
\hline public $[\%]$ & $8.23 \%$ & $6.12 \%$ & $7.81 \%$ & $6.22 \%$ & $5.08 \%$ \\
\hline apprentice $[\%]$ & $0.10 \%$ & $0.38 \%$ & $0.35 \%$ & $0.14 \%$ & $1.36 \%$ \\
\hline $\begin{array}{l}\text { white collar } \\
\text { worker [\%] }\end{array}$ & $21.91 \%$ & $29.20 \%$ & $24.48 \%$ & $26.56 \%$ & $26.44 \%$ \\
\hline $\begin{array}{l}\text { blue collar wor- } \\
\text { ker [\%] }\end{array}$ & $12.96 \%$ & $12.41 \%$ & $17.88 \%$ & $8.31 \%$ & $10.85 \%$ \\
\hline $\begin{array}{l}\text { family worker } \\
{[\%]}\end{array}$ & $0.29 \%$ & $0.98 \%$ & $0.69 \%$ & $4.65 \%$ & $5.08 \%$ \\
\hline
\end{tabular}




\begin{tabular}{|c|c|c|c|c|c|}
\hline \multicolumn{6}{|c|}{ HOUSEHOLD CHARACTERISTICS } \\
\hline $\begin{array}{l}\text { regular help } \\
\text { from other hhs } \\
\text { [hrs] }\end{array}$ & 1.31 & 1.81 & 1.89 & 1.89 & 2.01 \\
\hline REGIONAI & RIABLE & & & & \\
\hline $\begin{array}{l}\text { unemployment } \\
\text { rate }[\%]\end{array}$ & $9.61 \%$ & $10.32 \%$ & $9.38 \%$ & $9.34 \%$ & $9.53 \%$ \\
\hline $\begin{array}{l}\text { east Germany } \\
{[\%]}\end{array}$ & $20.22 \%$ & $28.43 \%$ & $17.01 \%$ & $19.18 \%$ & $20.68 \%$ \\
\hline GNP p.c. $[D M]$ & 36775 & 35002 & 37543 & 36794 & 37220 \\
\hline$n$ & 12773 & 8362 & 576 & 2925 & 295 \\
\hline
\end{tabular}

Significance levels: * 5\%,**1\%,*** $0.1 \%$

Source: $\quad$ German Time Use Survey 1991/92, own computations

\section{$5 \quad$ Working Hour Arrangements - Econometrics and Results}

Now let us consider the multivariate analyses. This section is about the explanation of the working hour arrangements defined above which are partitioned in the five categories of core and non-core working time with one respective two and more episodes. Category 0 is the reference category consisting of non-workers. According to the microeconomic model in general , prices, here wages, should play an determining role in explaining work patterns. Since for not working persons obviously there is no wage at hand, we estimate a potential wage for them, which then enriches the determination of the choice of working hour pattern by the MNL-model.

\subsection{Estimating potential wages for non workers: A selectivity bias corrected PROBIT/COLS approach}

\section{Econometric model}

The potential wage of those who are currently not working that day will be estimated by a two step selectivity bias corrected wage estimation PROBIT/COLS:

Step 1: Working: Estimation of the labour force participation or working probability (by PROBIT) with an unobservable variable I* (going to work or not) and an observable index $\mathrm{I}=1$ if working and $\mathrm{I}=0$ else, and the calculation of the 'selectivity bias' correction term $\lambda$ $=\phi\left(\alpha^{6} \mathbf{z}\right) / \Phi\left(\alpha^{6} \mathbf{z}\right)($ Mills' ratio $)$

$$
I^{*}=\alpha^{6} \mathbf{z}+\varepsilon_{1}
$$$$
\varepsilon_{1} \sim \mathrm{N}\left(0, \sigma_{1}{ }^{2}\right)
$$ 
Step 2: Wage: 'selectivity bias' corrected estimation (COLS) for workers only

$$
\begin{aligned}
& \mathrm{w}=\mathrm{w}(\mathbf{x})+\left(\rho \sigma_{\varepsilon 1}\right) \lambda+\varepsilon \\
& =\boldsymbol{\beta}^{\prime} \mathbf{x}+\theta \lambda+\varepsilon \\
& \varepsilon \sim N\left(0, \sigma^{2}\right)
\end{aligned}
$$

where the individual wage will be explained mainly by classical human capital variables $\mathrm{x}$ within the set of socio-economic variables.

\section{Results}

The results of estimating the potential wage equation are given in Table 5. The PROBIT equation for the probability of working and the determination of the selectivity correcting term $\lambda$ needs variables which are available for workers and non-workers. We follow a scarce specification and can divide the set of explanatory variables into personal and partner's characteristics. Compared to the reference person - characterized by a non-married man without a school leaving certificate and an occupational education where a possible partner is not working - all variables are highly significant.

Thus being a woman, being married will diminish the probability to work, whereas the human capital approach variables as school leaving and occupational education have the expected positive effects. In addition we included hours of regular help to other households as a social network variable. Such a social network obligation is diminishing the probability for paid working.

\begin{tabular}{|c|c|c|}
\hline & $\begin{array}{c}\text { Labour force } \\
\text { participation } \\
\text { PROBIT }\end{array}$ & $\begin{array}{c}\text { Wage } \\
\text { PROBIT/COLS }\end{array}$ \\
\hline Endogenous variable & Probability of working & In wage \\
\hline constant & $-2.5827293^{* * *}$ & $1.2289084^{* * *}$ \\
\hline \multicolumn{3}{|c|}{ PERSONAL CHARACTERISTICS } \\
\hline age & $0.1056814^{* * *}$ & $0.0765006^{* * *}$ \\
\hline $\operatorname{age}^{2} / 100$ & $-0.1430193^{* * *}$ & $-0.0727981^{* * *}$ \\
\hline woman & $-0.5213160^{* * *}$ & $-0.3094903^{* * *}$ \\
\hline married & $-0.1361333^{* * *}$ & - \\
\hline \multicolumn{3}{|c|}{ school leaving certificate } \\
\hline elemantary & $1.0421522 * * *$ & -0.0415300 \\
\hline intermed & $1.0889514^{* * *}$ & -0.0306680 \\
\hline Specialized upper & $1.0189338^{* * *}$ & 0.1224724 \\
\hline Upper(Abitur) & $1.0621669^{* * *}$ & 0.1215650 \\
\hline \multicolumn{3}{|l|}{ occupational education } \\
\hline apprentice & $0.2822337^{* * *}$ & $0.2606597^{* * *}$ \\
\hline spec. vocational & $0.4256431^{* * *}$ & $0.3947589 * * *$ \\
\hline
\end{tabular}

Tab. 5: $\quad$ Estimation of potential wages by a selectivity bias corrected PROBIT/COLS model 


\begin{tabular}{|c|c|c|c|c|}
\hline spec. college & 0.4589587 & *** & \multicolumn{2}{|c|}{$0.3642089 * * *$} \\
\hline university & 0.6004592 & *** & \multicolumn{2}{|c|}{$0.3825068^{* * *}$} \\
\hline \multicolumn{5}{|l|}{ social network } \\
\hline hours of regular help to other hhs & -0.0148885 & *** & \multicolumn{2}{|l|}{-} \\
\hline \multicolumn{5}{|l|}{ week } \\
\hline workday & - & & \multicolumn{2}{|c|}{$-0.1467864^{* * *}$} \\
\hline \multicolumn{5}{|c|}{ PARTNER'S CHARACTERISTICS } \\
\hline partner full time & -0.2298370 & *** & \multicolumn{2}{|l|}{-} \\
\hline partner self employed & 0.2216165 & *** & \multicolumn{2}{|l|}{-} \\
\hline partner employee & 0.1855687 & *** & \multicolumn{2}{|l|}{ - } \\
\hline number of persons in hh & -0.0570966 & *** & \multicolumn{2}{|l|}{-} \\
\hline \multicolumn{5}{|c|}{ REGIONAL CHARACTERISTICS } \\
\hline East Germany & - & & \multicolumn{2}{|c|}{$-0.5508408^{* * *}$} \\
\hline Lambda & - & & \multicolumn{2}{|c|}{$-0.3959340^{* * *}$} \\
\hline Goodness of fit & $\begin{array}{l}\text { Chi squared } \\
\text { Degrees of freedom } \\
\text { Prob[ChiSqd }>\text { value] } \\
.0000000 \\
\text { Count } R^{2}\end{array}$ & $\begin{array}{r}3372.132 \\
17\end{array}$ & $\begin{array}{l}R 2 \\
\text { Adj.R2 } \\
F[14,10715] \\
p \text {-value for } F \\
\text { Rho=-.42605 }\end{array}$ & $\begin{array}{c}23.76 \% \\
23.67 \% \\
238.61 \\
.0000\end{array}$ \\
\hline$n$ & 23503 & & \multicolumn{2}{|c|}{10730} \\
\hline
\end{tabular}

Significance levels: $* 5 \%, * * 1 \%, * * * 0.1 \%$

Source: $\quad$ German Time Budget Survey 1991/92, own computations

The (ln) wage equation follows a human capital specification with available variables connected with the work place. All variables are highly significant except the school leaving certificates. Age as a further catch-up variable is of diminishing influence the older a person is, wages are lower for women than for men, and occupational education is of different significant influence. A normal workday's wage is lower than a weekend's wage with its overtime premia. The wages are significant lower in East Germany than in West Germany.

After imputing the potential wages from the overall quite satisfying PROBIT/COLS wage estimates for the not working persons the set of explanatory variables for the MNL-model to explain the participation probability for a certain working hour arrangement category is prepared. 


\subsection{Explaining Participation in Working Hour Arrangement Categories by a Multinomial Logit (MNL)-Model}

We model the choice of a certain working hour arrangement category microeconomically based by a model of utility maximization: An individual with preferences over the set of alternatives $\mathrm{j}(\mathrm{j}=0, \ldots, \mathrm{J})$ will choose that alternative with the highest utility. This model is known as the Random Utility Model (RUM) (McFadden 1976, 1986) with

$$
I_{j}=1 \quad \text { if } u_{j}=\max \left(u_{0}, \ldots, u_{J}\right) ; \quad I_{j}=0 \text { else }
$$

The alternative specific utilities are specified as random variables $\underbrace{\beta_{j}}_{v_{i j}}$ and the disturbances are distributed with extreme value distribution. The alternative specific choice probabilities $\mathrm{P}_{\mathrm{j}} P_{i j}=\operatorname{Prob}[\underbrace{\varepsilon_{i k}-\varepsilon_{i j}}_{\mu_{k j}}<\underbrace{v_{i j}-v_{i k}}_{\omega_{j k}}]=F\left(\beta_{j} x\right) ;(j \neq k ; j, k=0, \ldots, J)$ with the extreme value cdf then is

$$
\mathrm{P}\left(I_{j}=1 \mid x\right)=\exp \left(\beta_{j}^{\prime} x_{i}\right) / \sum_{j=0}^{J} \exp \left(\beta_{j}^{\prime} x_{i}\right)
$$

The MNL-estimates of the probability to participate in different working arrangement categories are presented in Table 6 . Since the non-linear approach does not allow to directly quantify the single items' influence on the respective probability we show and discuss marginal effects which are computed at variables' sample means. A general remark: when speaking about 'choosing' a certain working hour arrangement keep in mind that the belonging to a certain category is always the result of the market process with its working chances and constraints.

\section{PERSONAL CHARACTERISTICS}

Personal demographics: age, both squared and not squared, has a significant influence on the respondents' choice probabilities in each category. Being female reduces the probability to work in any of our categories significantly. To be married decreases the probability for all working categories except category II.

School leaving certificate: the result on school education is more surprising. Any school leaving certificate seems to pave the way for a regular work day as in category I. A better school education might not protect from working at off-core times. In contrary, the probability in the non-core/one episode category III is raised compared to the reference. Signs for the interrupted categories II and IV are insignificant but tend towards minus. The MNL analysis of the educational variables shows that a better qualification in particular is significant for one episode working hour arrangements.

Occupational education: the effects of the occupational status largely tell the same story. While choosing a one episode workday becomes more likely occupational education reduces the risk to work in the interrupted schedule category II. In contrast to schooling, occupational education increases the probability to choose the most irregular category IV significantly. 
Our hypothesis, that private time use behaviour has an influence on the choice of the working hour arrangement, is confirmed by significant effects of help for other households. In line with the descriptive analysis we see a significant negative sign for the non-work alternative and a positive one for the regular work day (category I). The same applies to the workday variable. Being content with one's own time use behaviour lowers the probability to work in any of the four arrangements. A higher wage reduces the chance to fall into category I, II or IV. However, it increases the probability to work non-core/one episode.

\section{PARTNERS CHARACTERISTICS}

Regarding the partner's amount of regular weekly working hours there seems to be a substitutional relationship between the two partners decision to work or not. The more intensive the partner's work is, the lower is the probability for core-work. There is no significant influence for the non-core situations.

Occupational status: apart from the extent to which the partner works, her or his occupational status does also play a roll in one's choice of the working hour arrangement. The MNL analysis points out that any occupational status of the partner increases the probability to work at any working hour arrangement showing the so called 'additional worker' effect. Having a self-employed partner makes the choice of a one episode type arrangement more likely. This effect on the choice of category IV is not significant. Partners of apprentices and helping family members tend to choose the most irregular category IV more often than the reference.

\section{HOUSEHOLD CHARACTERISTICS}

The household context partially explains the choice in question. The number of household members reflects the number of children and elderly and can thus be regarded as a proxy for the degree to which one is needed at home. Accordingly, a larger household reduces the probability of a normal workday (category I). In contrast non-normal workday participation is not affected by the household size.

\section{REGIONAL CHARACTERISTICS}

With regard to regional demand side variables it can be seen that a relatively high regional unemployment rate in particular reduces non-core-one-episode jobs, whereas a more economic well-being region measured by GNP per capita is in favour of a normal. Thus higher regional unemployment as well as a higher regional income seems to be complementary here.

Living in the former East Germany significantly increases the probability to choose a standard working hour arrangement. However, the data are of 1991/92, just after the German unification, so that caution in the interpretation has to be considered here. 
Tab. 6: Explaining working hour arrangement probabilities: Multinomial Logit (MNL) estimates - Marginal Effects

\begin{tabular}{|c|c|c|c|c|c|}
\hline & $\begin{array}{c}\text { Category } 0 \\
\text { Not } \\
\text { working }\end{array}$ & $\begin{array}{c}\text { Category I } \\
\text { One episode } \\
- \\
\text { core }\end{array}$ & $\begin{array}{l}\text { Category II } \\
\begin{array}{l}\text { \# episodes } \\
\geq 2 \text { - } \\
\text { core }\end{array}\end{array}$ & $\begin{array}{c}\text { Category III } \\
\text { One episode } \\
\text { - } \\
\text { non-core }\end{array}$ & $\begin{array}{l}\text { Category IV } \\
\text { \# episodes } \\
\geq 2 \text { - } \\
\text { non-core }\end{array}$ \\
\hline $\begin{array}{l}\text { constant } \\
\text { PERSONAL C }\end{array}$ & $\begin{array}{l}1.813604^{* * *} \\
\text { IARACTERIS }\end{array}$ & $\begin{array}{l}-1.276747^{* \star *} \\
\text { TICS }\end{array}$ & $-0.096774^{* * *}$ & $-0.373301^{* * *}$ & $-0.066781^{* * *}$ \\
\hline age & $-0.053420^{* * *}$ & $0.039602^{* * *}$ & $0.003010^{* * *}$ & $0.008783^{* * *}$ & $0.002025^{* * *}$ \\
\hline $\operatorname{age}^{2} / 100$ & $0.068658^{* * *}$ & $-0.051771^{* * *}$ & $-0.003956 * * *$ & $-0.010555^{* * *}$ & $-0.002376 * * *$ \\
\hline woman & $0.297910^{* * *}$ & $-0.186724^{* * *}$ & $-0.011438^{* * *}$ & $-0.088795^{* * *}$ & $-0.010953 * * *$ \\
\hline \multicolumn{5}{|c|}{ school leaving certificate } & $-0.006238^{* *}$ \\
\hline reference: none & - & - & - & - & - \\
\hline elementary & $-0.514409 * * *$ & $0.390274^{* * *}$ & 0.001100 & $0.125727^{* * *}$ & -0.002692 \\
\hline intermediate & $-0.536867^{* * *}$ & $0.403672^{* * *}$ & -0.004617 & $0.143359 * * *$ & -0.005548 \\
\hline spec. upper & $-0.490912^{* * *}$ & $0.369471^{* * *}$ & 0.000017 & $0.128449 * * *$ & -0.007026 \\
\hline \multicolumn{6}{|c|}{ occupational education } \\
\hline reference: none & - & - & - & - & - \\
\hline apprentice & $-0.114277^{* \star *}$ & $0.088649 * * *$ & -0.000111 & 0.013738 * & $0.012001 * * *$ \\
\hline spec. vocational & $-0.195088^{* * *}$ & $0.127727^{* * *}$ & 0.000671 & $0.054287^{* * *}$ & $0.012403^{* * *}$ \\
\hline spec. college & $-0.228322^{* * *}$ & $0.176986^{* * *}$ & $-0.022348^{* *}$ & $0.064009^{* * *}$ & $0.009675 *$ \\
\hline university & $-0.274749^{* * *}$ & $0.146946^{* * *}$ & 0.001334 & $0.106728^{* * *}$ & $0.019742^{* * *}$ \\
\hline $\begin{array}{l}\text { hours of regular } \\
\text { help to other hhs }\end{array}$ & $0.007588^{* * *}$ & $-0.006998^{* * *}$ & 0.000122 & -0.000766 & 0.000055 \\
\hline workday & $-0.643379 * * *$ & $0.484562^{* * *}$ & -0.003509 & $0.164346^{* * *}$ & -0.002019 \\
\hline content & $0.174994^{* * *}$ & $-0.116948 * * *$ & -0.005563 * & $-0.048383^{* * *}$ & $-0.004099 * *$ \\
\hline (potential) wage & $0.002970^{* * *}$ & $-0.002582 * * *$ & $-0.000429 * * *$ & $0.000284^{* * *}$ & $-0.000242 * * *$ \\
\hline $\begin{array}{l}\text { PARTNER'S } \\
\text { normal weekly } \\
\text { working time } \\
\text { partner`s employ }\end{array}$ & $\begin{array}{l}\text { HARACTERI } \\
\qquad 0.003601 \text { *** } \\
\text { ent status }\end{array}$ & $\begin{array}{l}\text { STICS } \\
-0.003363^{* * *}\end{array}$ & $-0.000564^{* * *}$ & 0.000193 & 0.000133 * \\
\hline $\begin{array}{l}\text { reference: not } \\
\text { employed }\end{array}$ & - & - & - & - & - \\
\hline self-employed & $-0.255467^{* * *}$ & $0.144569 * * *$ & $0.027898^{* * *}$ & $0.078850 * * *$ & 0.004150 \\
\hline public & $-0.074393 * *$ & $0.066382^{* * *}$ & $0.020612^{* * *}$ & -0.007079 & -0.005521 \\
\hline apprentice & $-0.245180^{* *}$ & $0.218587^{* *}$ & 0.037439 & -0.028805 & 0.017959 ** \\
\hline $\begin{array}{l}\text { white collar } \\
\text { worker }\end{array}$ & $-0.126927^{* * *}$ & $0.108267^{* * *}$ & 0.014758 ** & 0.006817 & -0.002915 \\
\hline
\end{tabular}




\begin{tabular}{|c|c|c|c|c|c|}
\hline blue collar worker & $-0.152577^{* * *}$ & $0.126262^{* * *}$ & $0.025363^{* * *}$ & 0.002466 & -0.001514 \\
\hline helping family & $-0.560175^{* * *}$ & $0.317504 * * *$ & 0.012436 & $0.216005^{* * *}$ & $0.014230^{* * *}$ \\
\hline \multicolumn{6}{|c|}{ HOUSEHOLD CHARACTERISTICS } \\
\hline $\begin{array}{l}\text { number of persons } \\
\text { in hh }\end{array}$ & $0.031641^{* * *}$ & $-0.032080^{* * *}$ & -0.000003 & 0.000293 & 0.000148 \\
\hline $\begin{array}{l}\text { hours of regular } \\
\text { help from other } \\
\text { hhs }\end{array}$ & $-0.002852 * * *$ & $0.002124^{* * *}$ & 0.000164 & 0.000513 & 0.000050 \\
\hline \multicolumn{6}{|c|}{ REGIONAL VARIABLES } \\
\hline unemployment rate & 0.247561 & 0.383967 * & -0.006182 & $-0.622093^{* * *}$ & -0.003253 \\
\hline east Germany & $-0.033832 *$ & $0.064120^{* * *}$ & -0.007808 & $-0.018818 *$ & -0.003662 \\
\hline GNPp.c.[1000DM] & 0.000413 & 0.000854 & 0.000041 & $-0.001364^{* * *}$ & 0.000056 \\
\hline LR Statistic & 10695.20 & \multicolumn{4}{|c|}{ Pseudo $\mathrm{R}^{2}=19.50 \%$} \\
\hline Degrees of Freedom & 112.0 & \multirow{2}{*}{\multicolumn{4}{|c|}{ Count $\mathrm{R}^{2}=66.21 \%$}} \\
\hline Prob. Value for LR & .00000 & & & & \\
\hline$n$ & 12773 & 8362 & 576 & 2925 & 295 \\
\hline
\end{tabular}

Significance levels: * 5\%,**1\%,*** 0.1\%, Source: German Time Budget Survey 1990/91, own computations

To summarize the results: Diverse personal, partner, household and regional characteristic effects in a market and non-market context influence in different ways the probability to belong to a certain working hour arrangements; the timing of work time as well the fragmentation, the irregularity concerning multiple episodes are important for the working hour arrangement explanation.

\section{$6 \quad$ Working Hours in a market and non-market context - Econometrics and Results}

\subsection{Microeconometric Specification: A MNL/COLS Arrangement Specific Working Hour Model}

In principle, there are three discrete choice modelling analyzing concepts: the parametric, the semiparametric and the nonparametric concept. Roughly speaking, the nonparametric concept with a kernel density is the most general and robust, but the least precise. The semiparametric concept such as of Klein and Spady requires only probability properties of the underlying distribution function. Following Greene's evaluation the parametric concept allows additional precision according the data generating process. In this paper we follow the parametric concept. A further paper will show the differences in the results with respect to the other concepts.

To estimate the category specific hours of work $h_{j}=h_{j}(w, V, q \mid$ category $j)$ (see equation 4$)$ we follow therefore the two-step sample selectivity bias corrected estimation by Lee 1983, which generalizes the selection probability (Heckman 1979) to the multinomial case by a MNL/COLS-model 
Step 1: Working hour arrangement category participation: Estimation of the multinomial logit (MNL) model ${ }^{9}$ to obtain the category specific probabilities $\mathrm{Pj}$

$$
\mathrm{P}\left(I_{j}=1 \mid x\right)=\exp \left(\alpha_{j}^{\prime} x_{i}\right) / \sum_{j=0}^{J} \exp \left(\alpha_{j}^{\prime} x_{i}\right)
$$

and calculation of the selectivity correction terms $\lambda_{j}$ by

$$
\mathrm{H}_{\mathrm{j}}=\Phi^{-1}\left(\mathrm{P}_{\mathrm{j}}\right)
$$

$$
\lambda_{\mathrm{j}}=\varphi\left(\mathrm{H}_{\mathrm{j}}\right) / \Phi\left(\mathrm{H}_{\mathrm{j}}\right)
$$

where $\varphi$ resp. $\Phi$ are the normal density resp. cumulative distribution function.

Step 2: Daily arrangement specific working hours: category specific selectivity bias corrected working hours least squares estimation (COLS) for category specific workers only

$$
\begin{aligned}
h_{j} & =\beta^{\prime} x+\left(\rho_{j} \sigma_{j}\right) \varphi\left[H_{j}\left(\alpha_{j}^{\prime} v\right)\right] / \Phi\left[H_{j}\left(\alpha_{j}^{\prime} v\right)\right]+\varepsilon_{j} \\
& =\beta^{\prime} x+\left(\rho_{j} \sigma_{j}\right) \lambda_{j}+\varepsilon_{j} \\
& =\beta^{\prime} x+\theta_{j} \lambda_{j}+\varepsilon_{j}
\end{aligned}
$$

To yield the correct significances of the estimated parameters we need the appropriate asymptotic covariance matrix. According to Greene 1998 the appropriate asymptotic covariance is

$$
\begin{aligned}
& C=\left(W_{j}^{\prime} W_{j}\right)^{-1}\left[\sigma_{j}^{2} W_{j}^{\prime}\left(I-\rho_{j}^{2} \Delta_{j}\right) W_{j}+\theta_{j}^{2} F_{j} \Sigma F^{\prime}{ }_{j}\right]\left(W_{j}^{\prime} W_{j} W^{-1},\right. \\
& \Delta_{j}=\operatorname{diag}\left(\delta_{1 j}, \ldots, \delta_{N_{j} j}\right), \\
& \delta_{i j}=\lambda_{i j}^{2}+H_{i j} \lambda_{i j}, \\
& \Sigma=\text { asympotic cov ariance matrix of estimated } \\
& \alpha=\left[\alpha_{1}, \alpha_{2}, \ldots, \alpha_{j}\right] \\
& F=W_{j}^{\prime} G_{j}, \\
& \text { and } \\
& G_{j}=N_{j} x\left(J_{2}\right)=\partial\left[N_{j} x 1 \text { vector of } \lambda^{\prime} s\right] / \partial \alpha^{\prime} .
\end{aligned}
$$

$W_{j}$ is the $N_{j} \times\left(K_{1}+1\right)$ matrix of regressors used in the regressions including $\lambda_{j} . \mathrm{G}_{\mathrm{j}}$ is a matrix of derivatives of the lambdas with respect to the logit parameters and $G_{j}=\left\lfloor G_{1 j}, G_{2 j}, \ldots ., G_{J j}\right\rfloor$ The ith row of the $N_{j} \times K_{2}$ matrix $G_{s j}$ is $g_{i s j}^{\prime}=\left(\partial_{i j} / F_{i j}\right) q_{i s j} v_{i}^{\prime}$. The scalar $q_{i s j}$ depends on the choice: If seleciton is on $\mathrm{z}=0, q_{i s j}=-P_{0 i} P_{s i}, S=1, \ldots J$. If selection is on $\mathrm{z}=$ some other value,

\footnotetext{
${ }^{9}$ MNL-model as above but with another empirical specification, see section 6.2)
} 
say, $\mathrm{k}$, then, for the kth item, $q_{i k j}=P_{i k}\left(1-P_{i k}\right)$, while for all other items, $q_{i s j}=-P_{i k} P_{s k}, s=1, \ldots J$ but not equal to $k$.

\subsection{Explaining Arrangement Specific Working Hours in a market and non-market context}

We discuss the arrangement specific working hours based on the selectivity corrected hours of work estimates according to equation $7 \mathrm{~d}$ with its correct asymptotic covariance. The multinomial logit results for the first step, the selection of a specific arrangement category is already discussed above. Here, however, a compressed MNL-estimation with fewer variables is used for the selectivity correction. Without any further discussion here the interested reader is referred to these MNL-results in the Appendix Table B.

Though our model as described in chapter 2 is based on a microeconomic labour supply approach, it is extended mainly with regard to two dimensions:

1. extended by daily working arrangements with focus on core and non-core working time crossed by number of episodes, and

2. extended by labour demand factors in a market and non-market context.

Thus, in principle the two central parts are modelled as $\mathrm{P}($ choice $\mathrm{j})=\mathrm{P}\left(\mathbf{x}_{\text {market }}, \mathbf{x}_{\text {non-market }}\right)$

(MNL) and here as

$$
\left.\mathrm{h}_{\mathrm{j}}=\mathrm{h}_{\mathrm{j}}\left(\mathbf{x}_{\text {market}}, \mathbf{x}_{\text {non-market }}\right) \quad \text { (MNL/COLS }\right)
$$

Within the market context we shall test hypotheses according to supply and demand/regional factors; within the non-market context we shall test hypotheses concerning personal, partner and household factors.

The estimation results are given in Table 7 for our four working hour arrangement categories. Overall the goodness of fit measures are quite good for a cross-sectional estimation; however, category specific differences are pronounced. A first view on the results (goodness of fit, number of significant variables) confirms our general hypotheses:

The explanation of daily working hours are dependent on and different with regard to different daily working hour arrangements.

We discuss now these differences in detail by the different context sets: personal, firm side, partner, household and regional subsets.

\section{PERSONAL CHARACTERISTICS}

Personal demographics: Only age (specified non-linear) is significant in this subset. Increasing age, as a proxy for the state of living conditions in general, will increase hours of work in the non-core/one episode category. A gender influence and an influence of the family status is not significant in all the categories. This is in some contrast to known pure labour supply studies of weekly working hours and possible due to the more disaggregated daily approach.

School leaving certificate: Only non-core/one-episode's hours are influenced significantly by schooling. Hours are diminished by a higher school leaving certificate showing that lower educated tend to work longer in this non-normal working hour arrangement. 
Occupational status: The one episode categories are influenced significantly by the different self-employed and employee status. Remarkably, each of the occupational status has a different significant effect in explaining hours of work in the core/one episode case. For all 'nonnormal' arrangements the different occupations play no roll except for self-employed with employees in the non-core/one episode case.

Tab. 7: Daily working hours in different working hour arrangements; MNL/COLS estimates with correct asymptotic variance

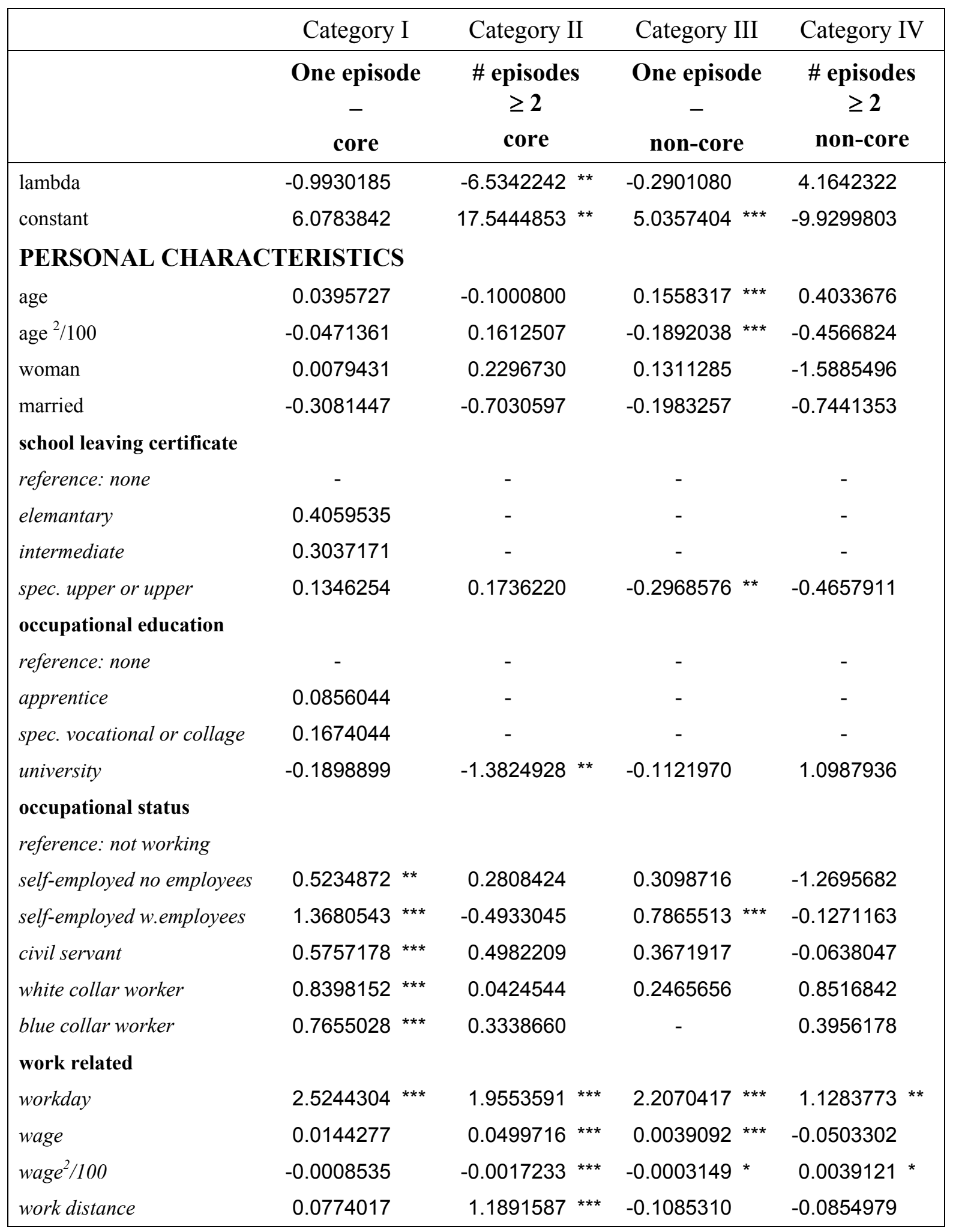




\begin{tabular}{|c|c|c|c|c|}
\hline second job & -0.0551767 & -0.4009990 & $0.5372906^{* * *}$ & -0.0987499 \\
\hline \multicolumn{5}{|l|}{ non-market time use } \\
\hline time for household & $-0.0130525^{* * *}$ & $-0.0088747^{* * *}$ & $-0.0128171^{* * *}$ & $-0.0155902^{* * *}$ \\
\hline time for child care & $-0.6395480^{* * *}$ & $-0.5083967^{* * *}$ & $-0.5661684^{* * *}$ & $-0.5346428^{* *}$ \\
\hline time for do-it-yourself & $-0.4815280^{* * *}$ & $-0.5053345^{* * *}$ & $-0.6596890^{* * *}$ & -0.2360144 \\
\hline content with time use & $-0.5694944^{* * *}$ & -0.1233049 & $-0.6548582 * * *$ & -0.7625407 \\
\hline \multirow{2}{*}{\multicolumn{5}{|c|}{$\begin{array}{l}\text { PARTNER CHARACTERISTICS } \\
\text { partner`s employment }\end{array}$}} \\
\hline & & & & \\
\hline weekly working time & 0.0138416 & 0.0186569 & $0.0120727^{* * *}$ & 0.0314107 \\
\hline self-employed & $-0.4497084^{* *}$ & 0.0712972 & $-0.5783906^{* *}$ & 0.0597193 \\
\hline employee & - & -0.0959214 & - & 0.1367850 \\
\hline $\begin{array}{l}\text { civil servant, blue or white } \\
\text { collar worker }\end{array}$ & - & - & $-0.3373018^{* *}$ & - \\
\hline civil servant & $-0.4396485^{* *}$ & - & - & - \\
\hline white collar worker & $-0.2813888 *$ & - & - & - \\
\hline blue collar worker & -0.2673026 & - & - & - \\
\hline \multicolumn{5}{|c|}{ HOUSEHOLD CHARACTERISTICS } \\
\hline \multicolumn{5}{|l|}{ Household size } \\
\hline number of persons in $h h$ & 0.0986427 & 0.0739545 & 0.0577271 & 0.2706140 \\
\hline \multicolumn{5}{|l|}{ Help received } \\
\hline $\begin{array}{l}\text { hours of regular help from } \\
\text { other hhs }\end{array}$ & - & - & 0.0078589 & - \\
\hline help received for household & 0.0046491 & -0.0529154 & - & $-0.1265191 *$ \\
\hline child care received & $0.0122073 *$ & 0.0353698 & - & 0.0452704 \\
\hline $\begin{array}{l}\text { assistance for adults recei- } \\
\text { ved }\end{array}$ & $0.0551494 * *$ & - & - & - \\
\hline \multicolumn{5}{|l|}{ Income/wealth situation } \\
\hline own house & 0.0787298 & 0.0268312 & 0.1551368 & -0.2664553 \\
\hline residual income & $-0.0641210 *$ & 0.0275070 & $-0.0409209 *$ & -0.0355461 \\
\hline \multicolumn{5}{|c|}{ REGIONAL VARIABLES } \\
\hline \multicolumn{5}{|l|}{ Demand side } \\
\hline \multicolumn{5}{|l|}{ business sectors } \\
\hline \multicolumn{5}{|l|}{ reference: agriculture } \\
\hline industry or retail & -0.1960700 & 0.7252267 & $-0.5397253 * * *$ & 0.4921579 \\
\hline private or public services & $-0.4545789 * * *$ & 0.6864330 & $-0.7919588^{* * *}$ & 0.9021219 \\
\hline unemployment & -0.0154005 & $0.1501287^{* *}$ & - & -0.0104312 \\
\hline east Germany & $1.0602623^{* * *}$ & 0.7473803 & $0.8842618^{* * *}$ & 0.3022304 \\
\hline GNP p.c. $[1000 D M]$ & 0.0020995 & 0.0081823 & - & 0.0026560 \\
\hline$R 2$ adj. & .49639 & .44820 & .38924 & .43720 \\
\hline$F$-Stat $(K ; n-K-1)$ & 202.00 & 14.74 & 63.12 & 7.72 \\
\hline
\end{tabular}




\begin{tabular}{|lcccc|}
\hline$p$-value for $F$ & $.00000^{* * *}$ & $.00000^{* * *}$ & $.00000^{* * *}$ & $.00000^{* * *}$ \\
$n$ & $8362^{* *}$ & $576^{*}$ & 2925 & 295 \\
\hline
\end{tabular}

Significance levels: $* 5 \%, * * 1 \%, * * * 0.1 \%$

Source: German Time Budget Survey 199192, own computations

Work related: The central economic explaining variable in the microeconomic labour supply world are wages. We specified a non-linear wage influence allowing for a second-order Taylor expansion approach for a non-linear hours equation. Remarkably, wages are only of significance for two non-normal working hour arrangement cases (!). With a positive sign higher wages increase the hours of work. Thus the substitution effect dominates the income effect in all the categories. Wages play no role in the most 'non-normal'-case: non-core/more than 2 episodes. The distance to the work place is only significant for category II.

A bit surprising is the influence of a second job in the one episode category 3. An explanation seems to be that the second job is not stringently connected with the day under consideration.

Non-market time use: Hours of work compete with hours in different other activities. In a first approach we include these variables as 'exogenous' variables, though a simultaneous approach might be favourable. However, in the context of a utility maximization approach under constraints those equations have not to be solved simultaneously but can be estimated in a seemingly unrelated regression context. Our utility based approach is in favour for our non-simultaneous approach. The results: in all working hour arrangements the working hours are significantly influenced by time spent for household activities, child care, do-it-yourself (not category 4). The content variable indicates in the one-episode categories only that preferred hours of work are lower than the actual amount of working hours.

\section{PARTNER CHARACTERISTICS}

Partner's employment: An additional worker effect is given in the non-core/one episode case: the more intensive the partner is working the more intense is the own labour supply. The core/one episode case in addition shows that the employment status of the partner diminishes differently and significantly the working hours compared to a non-employed partner. Remarkably in this first category only the employment status of the partner is important, not the hours intensity.

\section{HOUSEHOLD CHARACTERISTICS}

Household size: As a catch-up variable for the household environment the number of persons in the household is tested. The pure household size is of no significance. But remember, time spent for the household in different activities is important.

Help received: Received support in various ways is on the agenda of recent public politics to support the labour market. Indeed there is an influence visible, at least in the early 90ies: child care help and assistance for adults by other persons allow a longer workday. Help from other households only diminishes irregular working hours in the most non-normal category noncore/two and more episodes. In all other cases one can argue that despite of help those categories were or had to be chosen.

Income/wealth situation: To analyse the income situation of the entire household background this influence is tested by household net income minus own net income. Such a background income influence diminishes hours only in the one episode case but on a lower significance level. Owning the house where the household is living - as some wealth indicator - has no significant influence on the working hours in each category. The conclusion here might be that non-normal working arrangements are only weakly affected by the household in- 
come/wealth situation and the need for these jobs and money.

\section{REGIONAL CHARACTERISTICS}

Business sector: This demand side variable is divided into the three general sectors: agriculture (first), industry or retail (second) and private or public services (third). Significant influences are given only in the one episode cases with diminished hours compared to the agriculture reference. Thus, regardless the core or non-core situation the business sector is not affecting the amount of work.

Further demand side variables: The possibility to work, the demand side, is indicated in our approach by three variables: the regional unemployment rate, living in East Germany and as a regional wealth indicator per capita GNP. The results: a higher unemployment will cause more episodes to meet the needs. In East Germany the working hours in one episodes are significantly longer. The general economic situation in the region where the household is living is not influencing the hours of work in either category.

\section{Summary}

To summarize our results an overview of significant explanatory factors of daily working hours in different working hour arrangements is given in Tab. 8.

Tab. 8: Daily working hours in different working hour arrangements; An overview of significant explanatory factors

\begin{tabular}{|c|c|c|c|c|}
\hline & $\begin{array}{c}\text { Category I } \\
\text { One episode } \\
- \\
\text { core }\end{array}$ & $\begin{array}{l}\text { Category II } \\
\text { \# episodes } \\
\geq 2 \\
\text { core }\end{array}$ & $\begin{array}{c}\text { Category III } \\
\text { One episode } \\
- \\
\text { non-core }\end{array}$ & $\begin{array}{c}\text { Category IV } \\
\text { \# episodes } \\
\geq 2 \\
\text { non-core }\end{array}$ \\
\hline & part. hours & part. hours & part. hours & part. hours \\
\hline \multicolumn{5}{|c|}{ PERSONAL CHARACTERISTICS } \\
\hline Demographics & $* * *$ & \multirow[t]{2}{*}{$* * *$} & \multirow{2}{*}{ 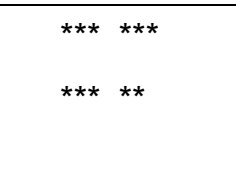 } & \multirow[t]{2}{*}{$* * *$} \\
\hline $\begin{array}{l}\text { school leaving certifi- } \\
\text { cate }\end{array}$ & *** & & & \\
\hline occupational education & *** & ** & *** & *** \\
\hline occupational status & $-* * *$ & - & $-\left({ }^{* * *}\right)$ & - \\
\hline business sectors & $-* * *$ & - & $-* * *$ & - \\
\hline work related (wage) & $* * *$ & $* * * * * *$ & $* * * * * *$ & $* * *$ \\
\hline non-market time use & $-* * *$ & $-* * *$ & $-* * *$ & $-* *$ \\
\hline \multicolumn{5}{|c|}{ PARTNER CHARACTERISTICS } \\
\hline partner`s employment & $* * * * *$ & $* * *$ & $(* * *) * *$ & $(* * *)$ \\
\hline \multicolumn{5}{|c|}{ HOUSEHOLD CHARACTERISTICS } \\
\hline Household size & \multirow{3}{*}{$\begin{array}{c}\text { *** } \\
* * * * * \\
{ }_{-}^{*}\end{array}$} & \multirow[b]{3}{*}{-} & \multirow[b]{3}{*}{- * } & \multirow{3}{*}{ * } \\
\hline Help received & & & & \\
\hline $\begin{array}{l}\text { Income/wealth } \\
\text { situation }\end{array}$ & & & & \\
\hline
\end{tabular}




\begin{tabular}{|c|c|c|c|}
\hline REGIONAI & ES & & \\
\hline Demand side & $\left({ }^{* * *}\right) * * *$ & $* *$ & $* * * * * *$ \\
\hline
\end{tabular}

Significance levels: * $5 \%, * * 1 \%, * * * 0.1 \%$

Source: $\quad$ German Time Budget Survey 1991/92, own computations

Interpreting the stylized variable packages of Table 8 we can conclude with the overall hypothesis: The driving factors of so-called 'normal' and ,non-normal' workdays are quite different: the timing of work time as well as the fragmentation of the working period have to be explained by different hypotheses. The results support our modelling and in particular the two stage explanation: the probability to participate to a certain daily working hour arrangement shows different explanatory patterns than the final hours of work. Central variables from a microeconomic model like wages are important for the final hours, however, are not important for the participation probability. The positive wage coefficient here shows a dominant substitution effect vs. an income effect not in the polar cases 'normal day' (category I) and most irregular day (category IV), but in the off-diagonal cases of Table 3 core/multiple episodes and non-core/one episode. In addition, further personal variables, like human capital, other work related variables, and non-market time use, partner's and household characteristics as well as demand side and regional variables are important but of different influence in explaining working hours in different working hour arrangements.

\section{$7 \quad$ Concluding remarks}

In this paper we analysed working hour arrangements and working hours based on time diary data of the German Time Use Survey 1991/92. Only time diary data sufficiently provide information about the timing of work time allowing the investigation of the fragmentation of a working day linked with the location of working periods, the timing of work time. Our study proved that both dimensions are important to explain daily working hour arrangements and its working hours in Germany.

We quantified diverse personal, partner, household and regional characteristic effects by microeconometric estimates - based on an extended microeconomic model..

The driving factors of so-called 'normal' and ,non-normal' workdays thus are quite different. In a different way market and non-market context with labour supply and labour demand side variables are important to explain working hour arrangements and the resulting working time in Germany.

Further research will compare these interesting and striking results with the very new German Time Use Study 2002 and other international time use diary results of working hour arrangements. 


\section{Appendix}

Tab. A: Sensitivity of work episode definition by length of interruption

\begin{tabular}{|c|c|c|c|c|c|c|c|c|c|}
\hline \multirow{2}{*}{$\begin{array}{l}\text { No. of } \\
\text { epi- } \\
\text { sodes }\end{array}$} & \multicolumn{3}{|c|}{$\begin{array}{c}\text { frequencies } \\
\geq 15 \text { min. interruption }\end{array}$} & \multicolumn{3}{|c|}{$\begin{array}{c}\text { frequencies } \\
\geq 30 \text { min. interruption }\end{array}$} & \multicolumn{3}{|c|}{$\begin{array}{c}\text { frequencies } \\
\geq 60 \text { min. interruption }\end{array}$} \\
\hline & $\mathrm{n}$ & $\%$ & $\%$ cum. & n. & $\%$ & $\%$ cum. & $\mathrm{n}$ & $\%$ & $\begin{array}{c}\% \\
\text { cum. }\end{array}$ \\
\hline 1 & 3752 & 29,2 & 29,2 & 4693 & 36,5 & 36,5 & 9301 & 72,3 & 72,3 \\
\hline 2 & 5954 & 46,3 & 75,5 & 6461 & 50,2 & 86,7 & 2877 & 22,4 & 94,7 \\
\hline 3 & 2207 & 17,2 & 92,6 & 1221 & 9,5 & 96,2 & 549 & 4,3 & 99,0 \\
\hline 4 & 617 & 4,8 & 97,4 & 344 & 2,7 & 98,9 & 102 &, 8 & 99,8 \\
\hline 5 & 213 & 1,7 & 99,1 & 111 & ,9 & 99,8 & 29 & ,2 & 100,0 \\
\hline 6 & 80 & ,6 & 99,7 & 25 & ,2 & 100,0 & 2 & , 0 & 100,0 \\
\hline 7 & 25 & ,2 & 99,9 & 4 & ,0 & 100,0 & 0 & ,0 & 100,0 \\
\hline 8 & 9 & ,1 & 100,0 & 1 &, 0 & 100,0 & 1 &, 0 & 100,0 \\
\hline 9 & 3 &, 0 & 100,0 & 1 &, 0 & 100,0 & 0 &, 0 & 100,0 \\
\hline 10 & 0 &, 0 & 100,0 & 0 &, 0 & 100,0 & 0 &, 0 & 100,0 \\
\hline 11 & 1 &, 0 & 100,0 & 0 &, 0 & 100,0 & 0 &, 0 & 100,0 \\
\hline Total & 12861 & 100,0 & & 12861 & 100,0 & & 12861 & 100,0 & \\
\hline
\end{tabular}

Source: $\quad$ German Time Budget Survey 1990/91, own computations 
Tab. B: Working hour arrangement MNL-estimation for the selectivity correction estimates of working hours

\begin{tabular}{|c|c|c|c|c|c|}
\hline & $\begin{array}{l}\text { Category } 0 \\
\text { Not work- } \\
\quad \text { ing }\end{array}$ & $\begin{array}{l}\text { Category I } \\
\text { One epi- } \\
\text { sode } \\
- \\
\text { core }\end{array}$ & $\begin{array}{l}\text { Category II } \\
\text { \# episodes } \\
\geq 2 \\
\text { core }\end{array}$ & $\begin{array}{c}\text { Category III } \\
\text { One episode } \\
- \\
\text { non-core }\end{array}$ & $\begin{array}{l}\text { Category IV } \\
\text { \# episodes } \\
\geq 2 \\
\text { non-core }\end{array}$ \\
\hline constant & $1.43809 * * *$ & $-0.93283^{* * *}$ & $0.08949 * * *$ & $-0.34659 * * *$ & $-0.06917^{* * *}$ \\
\hline \multicolumn{6}{|c|}{ PERSONAL CHARACTERISTICS } \\
\hline age & $-0.05708^{* * *}$ & $0.04515^{* * *}$ & $0.00267^{* * *}$ & $0.00695^{* * *}$ & $0.00232^{* * *}$ \\
\hline age $2 / 100$ & $0.07292 * * *$ & $-0.05854^{* * *}$ & $-0.00353^{* * *}$ & $-0.00818^{* * *}$ & $-0.00267^{* * *}$ \\
\hline woman & $0.28922 * * *$ & $-0.17964^{* * *}$ & $-0.00964^{* * *}$ & $-0.08918^{* * *}$ & $-0.01076^{* * *}$ \\
\hline $\begin{array}{l}\text { married } \\
\text { school leaving certifi } \\
\text { reference: none or } \\
\text { intermediate }\end{array}$ & $\begin{array}{l}0.04713^{* * *} \\
\text { cate }\end{array}$ & 0.00568 & 0.00809 * & $-0.05431^{* * *}$ & $-0.00659 * * *$ \\
\hline $\begin{array}{l}\text { elementary } \\
\text { spec. upper or up- } \\
\text { per }\end{array}$ & $\begin{array}{l}-0.52999^{* * *} \\
-0.51052^{* * *}\end{array}$ & $0.39036^{* * *}$ & -0.00822 & $\begin{array}{l}0.14052^{* * *} \\
0.12994^{* * *}\end{array}$ & $\begin{array}{r}0.00127 \\
-0.00156\end{array}$ \\
\hline $\begin{array}{l}\text { occupational educat } \\
\text { reference: none or } \\
\text { apprenticeship } \\
\text { spec. vocational or } \\
\text { college }\end{array}$ & $-0.10988^{* * *}$ & $52 * * *$ & -0.00419 & $6^{* * *}$ & \\
\hline university & $-0.17453^{* * *}$ & $0.06557^{* * *}$ & 0.00101 & $0.09937^{* * *}$ & $0.00859^{* * *}$ \\
\hline $\begin{array}{l}\text { (potential) wage } \\
\text { normal weekly } \\
\text { working time }\end{array}$ & $\begin{array}{l}0.00494^{* * *} \\
-0.00003\end{array}$ & $\begin{array}{l}-0.00484^{* * *} \\
-0.00108^{* * *}\end{array}$ & $\begin{array}{l}-0.00034^{* * *} \\
-0.00013^{*}\end{array}$ & $\begin{array}{l}0.00046^{* * *} \\
0.00109^{* * *}\end{array}$ & $\begin{array}{l}-0.00022^{* * *} \\
0.00015^{* * *}\end{array}$ \\
\hline $\begin{array}{l}\text { HOUSEHOLD C } \\
\text { number of persons } \\
\text { in hh }\end{array}$ & $\begin{array}{r}\text { HARACTER } \\
0.01992^{* * *}\end{array}$ & $\begin{array}{l}\text { STICS } \\
-0.02750^{* * *}\end{array}$ & 0.00015 & $0.00697 * * *$ & 0.00046 \\
\hline REGIONAL VA & RIABLES & & & & \\
\hline unemployment rate & -0.26638 & $0.59914^{* * *}$ & -0.00707 & $-0.31283^{* * *}$ & -0.01286 \\
\hline East Germany & 0.00641 & 0.01328 & -0.00678 & -0.01054 & -0.00236 \\
\hline $\begin{array}{l}\text { LR Statistic } \\
\text { Degrees of Freedom } \\
\text { Prob. Value for LR }\end{array}$ & $\begin{array}{l}4768.73 \\
52 \\
.00000 \\
\end{array}$ & & $\begin{array}{l}\text { Pseudo } \\
\text { Count I }\end{array}$ & $\begin{array}{l}\mathrm{R}^{2}=8.69 \% \\
=61.00 \%\end{array}$ & \\
\hline$n$ & 12773 & 8362 & 576 & 2925 & 295 \\
\hline
\end{tabular}

Significance levels: * $5 \%, * * 1 \%, * * * 0.1 \%$

Source: $\quad$ German Time Budget Survey 1990/91, own computations 


\section{References}

Bauer, F., Groß, H., Munz, E. and S. Sayin (2001), Arbeits- und Betriebszeiten, Neue Formen des betrieblichen Arbeits- und Betriebszeitmanagements, Düsseldorf.

Becker, G.S. (1965), A Theory of the Allocation of Time, in: Economic Journal, 75, 493-517.

Büssing, A. and H. Seifert (1995), Sozialverträgliche Arbeitszeitgestaltung, München.

Clarkberg, M. and Ph. Moen (2000), Understanding the Time Squeeze: Married Couples Preferred and Actual Work-Hour Strategies, in: American Behavioral Scientist, 44/7, 1115-1136.

Ehling, M. (1999), The German Time Use Survey - Methods and Results, in: Merz, J. and M. Ehling (eds.), Time Use - Research, Data and Policy, Publications of the Research Institute on Professions (FFB) of the University of Lüneburg, , Vol. 10, Baden-Baden, 89-105.

Federal Statistical Office Germany (1992): Handbuch zu, Wo bleibt die Zeit ?', Wiesbaden.

Garhammer, M. (1994), Balanceakt Zeit: Auswirkungen flexibler Arbeitszeiten auf Alltag, Freizeit und Familie, Edition Sigma, Berlin.

Greene, W. (1998), LIMDEP Version 7/8, Plainview, New York, 1998/2002.

Greene, W. (2000), Econometric Analysis, 4th edition, Prentice Hall, Upper Saddle River, 2000.

Ham, J. C. (1982), Estimation of a Labour Supply Model with Censoring Due to Unemployment and Underemployment, in: Review of Economic Studies, 69, 335-54.

Hamermesh, D. (1996a), The Timing of Work Time, in: Konjunkturpolitik, Applied Economics Quarterly, $42: 1$ 22.

Hamermesh, D. (1996b), Workdays, Workhours and Work Schedules, W. E. Upjohn Institute for Employment Research, Kalamazoo, Michigan.

Hamermesh, D. (1998), When we work, American Economic Review, 88: 321 - 325.

Hamermesh, D. (2002), Timing, togetherness and time windfalls, Journal of Population Economics, 15: 321 325.

Harvey, A. (1999), Time Use Research: The Roots to the Future, , in: Merz, J. and M. Ehling (eds.), Time Use Research, Data and Policy, Publications of the Research Institute on Professions (FFB) of the University of Lüneburg, , Vol. 10, Baden-Baden, 123-49.

Harvey, A. Fisher, K., Gershuny, J. and A. Akbari (2000), Examining Working Time Arrangements Using Time Use Surveys, ISER working paper No. 20, Essex.

Holst, E. and J. Schupp, J. (1994), Ist Teilzeitarbeit der richtige Weg? Arbeitszeitpräferenzen in West- und Ostdeutschland, DIW-Wochenbericht, 35/94, 618-26, 1994.

Killingsworth, M.R. (1983), Labor supply, Cambridge.

Killingsworth, M.R. and J.J. Heckman (1986), Female Labor Supply: A Survey, in: Ashenfelter, O. and R. Layard (eds.) (1986), Handbook of Labor Economics, Vol I, Amsterdam/New York, 103-204.

Lee, L.-F.(1983), Generalized econometric models with selectivity, Econometrica, 51(2): 507-512.

Madalla, G.S. (1983), Limited Dependent and Qualitative Variables in Econometrics, Cambridge/London.

McFadden, D. (1976), Quantal Choice Analysis: A Survey. Annals of Economic and Social Measurement

McFadden, D.L. (1985), Econometric Analysis of Qualitative Response Models, in: Griliches, Z. and M.D. Intriligator (eds.), Handbook of Econometrics, Volume II, Amsterdam/New York, 1395-457.

Merz, J. (1990), Female Labour Supply: Labour Force Participation, Market Wage Rate and Working Hours of Married and Unmarried Women in the Federal Republic of Germany - The Influence of Occupational Career, Transfers and Socio-Economic Variables Based on the Socio-Economic Panel, in: Jahrbücher für Nationalökonomie und Statistik, 240-70

Merz, J. (1990), The 1990 German Tax Reform - Microsimulation of Time Allocation Effects in the Formal and Informal Economy, in: Brunner, J. G. and H.-G. Petersen (Eds.), Prospects and Limits of Simulation Models in Tax and Transfer Policy, Frankfurt/New York, 509-37. 
Merz, J. (2002), Time and Economic Well-Being - A Panelanalysis of Desired vs. Actual Working Hours, in: The Review of Income and Wealth, 48/3, 317-46.

Merz, J. (2002), Time Use Research and Time Use Data - Actual Topics and New Frontiers, in: Ehling, M. and J. Merz (Eds.), Neue Technologien in der Umfrageforschung - Anwendungen bei der Erhebung von Zeitverwendung, Schriften des Forschungsinstituts Fr3eie Berufe (FFB) der Universität Lüneburg, Baden-Baden, 3-19.

Merz, J. and M. Ehling (1999), Time Use - Research, Data and Policy, Nomos Verlagsgesellschaft, BadenBaden.

Pencavel, J. (1986), Labor Supply of Men: A Survey, in: Ashenfelter, O. and R. Layard (eds.) (1986), Handbook of Labor Economics, Vol I, Amsterdam/New York, 3-102.

Townsend, B. (2001), Dual -Earner Couples and Long Work Hours: A Structural and Life Course Perspective," Berkeley Journal of Sociology.

van Soest, A., Woittiez, I. and A. Kapteyn (1989), Labour Supply, Income Taxes and Hours Restrictions in the Netherlands, Center for Economic Research, Tilburg University, Discussion Paper No. 8903, Tilburg.

Schupp, J. (1994), Teilzeitbeschäftigung im sozialen Wandel - Längsschnittanalysen und handlungstheoretische Fundierung (Dissertation), Bochum,: Ruhr-Universität. 


\section{IZA Discussion Papers}

\begin{tabular}{|c|c|c|c|c|}
\hline No. & Author(s) & Title & Area & Date \\
\hline 908 & M. Leonardi & Product Demand Shifts and Wage Inequality & 1 & $10 / 03$ \\
\hline 909 & M. Leonardi & $\begin{array}{l}\text { Firm Heterogeneity in Capital/Labor Ratios and } \\
\text { Wage Inequality }\end{array}$ & 1 & $10 / 03$ \\
\hline 910 & $\begin{array}{l}\text { P. Díaz-Vázquez } \\
\text { D. Snower }\end{array}$ & $\begin{array}{l}\text { On-the-Job Training, Firing Costs and } \\
\text { Employment }\end{array}$ & 5 & $10 / 03$ \\
\hline 911 & J. Wagner & $\begin{array}{l}\text { Are Nascent Entrepreneurs Jacks-of-all-Trades? } \\
\text { A Test of Lazear's Theory of Entrepreneurship } \\
\text { with German Data }\end{array}$ & 5 & $10 / 03$ \\
\hline 912 & $\begin{array}{l}\text { D. Checchi } \\
\text { A. Filippin }\end{array}$ & An Experimental Study of the POUM Hypothesis & 1 & $10 / 03$ \\
\hline 913 & $\begin{array}{l}\text { S. Pivnenko } \\
\text { D. DeVoretz }\end{array}$ & $\begin{array}{l}\text { The Recent Economic Performance of Ukrainian } \\
\text { Immigrants in Canada and the U.S. }\end{array}$ & 1 & $10 / 03$ \\
\hline 914 & $\begin{array}{l}\text { A. R. Cardoso } \\
\text { P. Portugal }\end{array}$ & $\begin{array}{l}\text { Bargained Wages, Wage Drift and the Design of } \\
\text { the Wage Setting System }\end{array}$ & 5 & $10 / 03$ \\
\hline 915 & $\begin{array}{l}\text { R. Hujer } \\
\text { C. Zeiss }\end{array}$ & $\begin{array}{l}\text { Macroeconomic Impacts of ALMP on the } \\
\text { Matching Process in West Germany }\end{array}$ & 6 & $10 / 03$ \\
\hline 916 & $\begin{array}{l}\text { S. C. Wolter } \\
\text { S. Mühlemann } \\
\text { J. Schweri }\end{array}$ & $\begin{array}{l}\text { Why Some Firms Train Apprentices and Many } \\
\text { Others Do Not }\end{array}$ & 5 & $10 / 03$ \\
\hline 917 & $\begin{array}{l}\text { R. Euwals } \\
\text { H. Roodenburg }\end{array}$ & $\begin{array}{l}\text { A Note on the Redistributive Effect of } \\
\text { Immigration }\end{array}$ & 1 & $10 / 03$ \\
\hline 918 & $\begin{array}{l}\text { V. Jakobsen } \\
\text { M. Rosholm }\end{array}$ & $\begin{array}{l}\text { Dropping out of School? A Competing Risks } \\
\text { Analysis of Young Immigrants' Progress in the } \\
\text { Educational System }\end{array}$ & 1 & $10 / 03$ \\
\hline 919 & M. Fertig & $\begin{array}{l}\text { The Impact of Economic Integration on } \\
\text { Employment - An Assessment in the Context of } \\
\text { EU Enlargement }\end{array}$ & 2 & 10/03 \\
\hline 920 & $\begin{array}{l}\varnothing . \text { A. Nilsen } \\
\text { K. G. Salvanes } \\
\text { F. Schiantarelli }\end{array}$ & $\begin{array}{l}\text { Employment Changes, the Structure of } \\
\text { Adjustment Costs, and Plant Size }\end{array}$ & 1 & $11 / 03$ \\
\hline 921 & $\begin{array}{l}\text { P. Egger } \\
\text { M. Pfaffermayr } \\
\text { A. Weber }\end{array}$ & $\begin{array}{l}\text { Sectoral Adjustment of Employment: The Impact } \\
\text { of Outsourcing and Trade at the Micro Level }\end{array}$ & 2 & $11 / 03$ \\
\hline 922 & $\begin{array}{l}\text { J. Merz } \\
\text { D. Burgert }\end{array}$ & $\begin{array}{l}\text { Working Hour Arrangements and Working Hours } \\
\text { - A Microeconometric Analysis Based on } \\
\text { German Time Use Diary Data }\end{array}$ & 5 & $11 / 03$ \\
\hline
\end{tabular}

An updated list of IZA Discussion Papers is available on the center's homepage www.iza.org. 